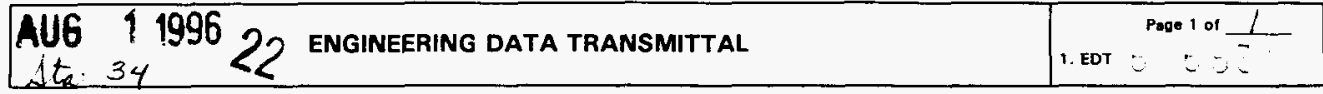

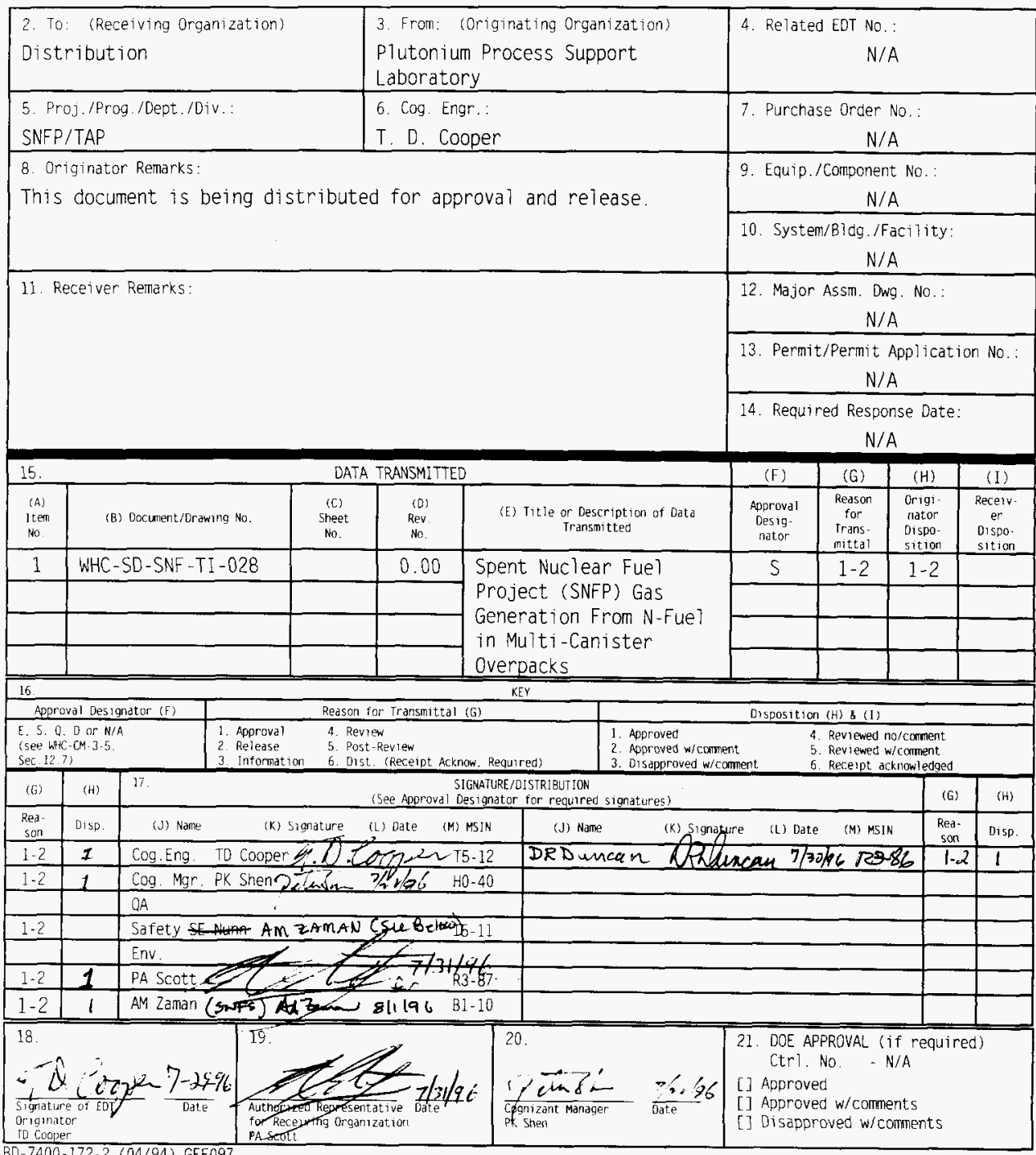

BD-7400-172-2 (04/94) GEF097 


\section{Spent Nuclear Fuel Project (SNFP) \\ Gas Generation From N-Fuel in Multi-Canister Overpacks}

\section{Thurman D. Cooper}

Westinghouse Hanford Company, Richland, WA 99352

U.S. Department of Energy Contract DE-AC06-87RL10930

EDT/ECN: 616631

Org Code: 15500

B\&R Code: EW3135040
UC: 510

Charge Code: LB040

Total Pages: $75,77 y_{8.1}^{w}-96$

Key Words: Gas Generation, MCO, N-Fuel

Abstract:

During the conversion from wet pool storage for spent nuclear fuel at Hanford, gases will be generated from both radiolysis and chemical reactions. The gas generation phenomenon needs to be understood as it applies to safety and design issues, specifically over pressurization of sealed storage containers, and detonation/deflagration of flammable gases. This study provides an initial basis to predict the implications of gas generation on the proposed functional processes for spent nuclear fuel conversion form wet to dry storage. These projections are based upon examination of the history of fuel manufacture at Hanford, irradiation in the reactors, corrosion during wet pool storage, available fuel characterization data and available information from literature. Gas generation via radiolysis and metal corrosion are addressed. The study examines gas generation, the boundary conditions for low medium and high levels of sludge in SNF storage/processing containers. The functional areas examined include: flooded and drained Multi Canister Overpacks, cold vacuum drying, shipping and staging, and long term storage.

TRADEMARK DISCLAIMER. Reference herein to any specific commercial product, process, or service by trade name, trademark, manufacturer, or otherwise, does not necessarily constitute or imply its endorsement, recommendation, or favoring by the United States Government or any agency thereof or its contractors or subcontractors.

Printed in the United States of America. To obtain copies of this document, contact: WHC/BCS Document Control Services, P.O. Box 1970, Mailstop H6-08, Richland WA 99352, Phone (509) 372-2420; Fax (509) 376-4989.
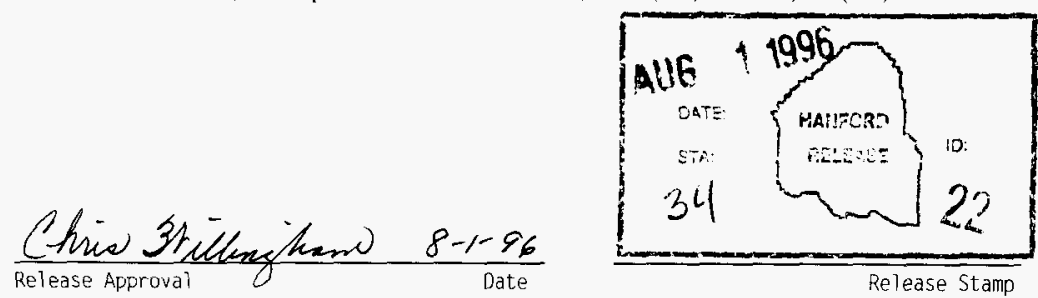

\section{Approved for Pub7ic Release}




\section{SPENT NUCLEAR FUEL PROJECT GAS GENERATION FROM N-FUEL IN MULTI-CANISTER OVERPACKS}

July 1996

Prepared for the U.S. Department of Energy

Office of Environmental Restoration and Waste Management

Westinghouse Hanford Company

P.O. Box 1970

Richland, Washington 99352 
This page intentionally left blank. 


\section{CONTENTS}

1.0 INTRODUCTION $\ldots \ldots \ldots \ldots \ldots \ldots \ldots \ldots \ldots \ldots \ldots \ldots \ldots \ldots \ldots \ldots \ldots \ldots$

2.0 FLOODED MULTI-CANISTER OVERPACK CASE $\ldots \ldots \ldots \ldots \ldots \ldots \ldots \ldots \ldots$.

2.1 UNCORRODED FUEL IN A FLOODED MCO $\ldots \ldots \ldots \ldots \ldots \ldots \ldots \ldots \ldots$.

2.1.1 Calculation of Radiolytic Gas Generation Rates $\ldots \ldots \ldots \ldots \ldots \ldots \ldots$. . . . . . . .

2.2 CORRODED FUEL IN A FLOODED MCO $\ldots \ldots \ldots \ldots \ldots \ldots \ldots \ldots \ldots \ldots \ldots$

2.2.1 Radiolytic Gases . . . . . . . . . . . . . . . . . . . . . 2-8

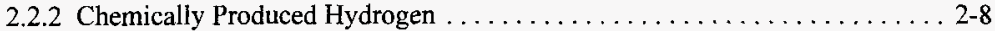

2.2.3 Hydrogen Generation from Reaction of Hydrides . . . . . . . . . . . . 2-10

2.3 FISSION PRODUCT GAS RELEASE IN A FLOODED MCO $\ldots \ldots \ldots \ldots \ldots .2-15$

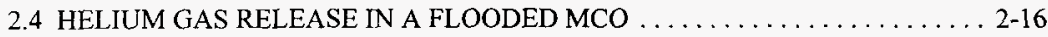

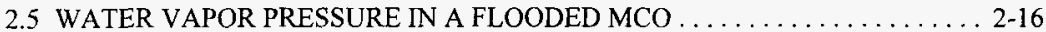

2.6 PRESSURIZATION OF A SEALED FLOODED MCO $\ldots \ldots \ldots \ldots \ldots \ldots \ldots \ldots$

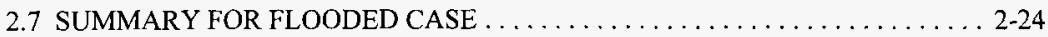

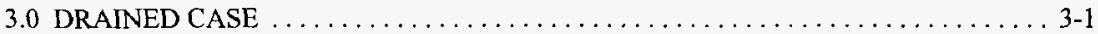

3.1 UNCORRODED FUEL IN A DRAINED MCO $\ldots \ldots \ldots \ldots \ldots \ldots \ldots \ldots \ldots . \ldots \ldots$

3.2 CORRODED FUEL IN A DRAINED MCO $\ldots \ldots \ldots \ldots \ldots \ldots \ldots \ldots \ldots \ldots .3$

3.2.1 Hydrogen Generated by Water Reaction on Uranium Metal in a Drained MCO ............................... 3-3

3.2.2 Hydrogen Generated by Water Reaction on Uranium Hydride in a Drained

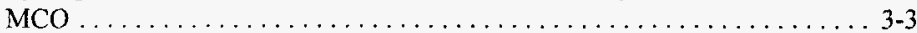

3.2.3 Fission Product Gas Release in a Drained MCO . . . . . . . . . . . 3-3

3.2.4 Helium Gas Release in a Drained MCO . . . . . . . . . . . . . . . . . 3-3

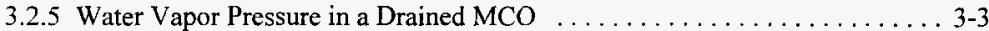

3.2.6 Pressurization of a Sealed Drained $\mathrm{MCO} \ldots \ldots \ldots \ldots \ldots \ldots \ldots \ldots . . . \ldots \ldots$

4.0 COLD VACUUM DRYING $\ldots \ldots \ldots \ldots \ldots \ldots \ldots \ldots \ldots \ldots \ldots \ldots \ldots \ldots \ldots$.

4.1 RADIOL YTIC GAS PRODUCTION FOR UNCORRODED FUEL DURING

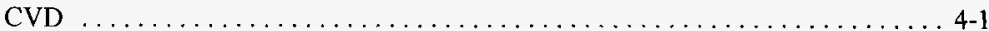

4.2 GAS GENERATION FROM CORRODED FUEL DURING CVD . . . . . . . 4 4-1

4.2.1 Hydrogen Generation from Water Reaction with Uranium Metal During CVD . . . . . . . . . . . . . . . . . . . . . . . .

4.2.2 Hydrogen Generation from Water Reaction with Uranium Hydride During

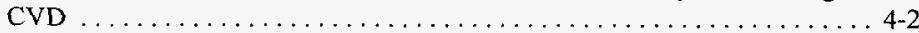

4.2.3 Fission Product Gas Release During CVD . . . . . . . . . . . . . 4-2

4.2.4 Helium Gas Release During CVD . . . . . . . . . . . . . . . . . . 4-4

4.2.5 Water Vapor Pressure Increase During CVD . . . . . . . . . . . . . . . 4-4

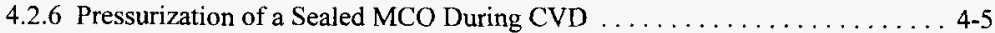




\section{CONTENTS cont.}

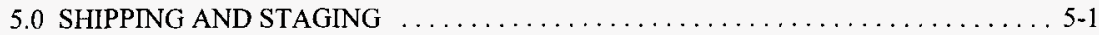

5.1 RADIOLYTIC GAS PRODUCTION ..................... $5-1$

5.2 CHEMICAL GAS GENERATION DURING SHIPPING AND STAGING $\ldots \ldots .5-2$

5.2.1 Estimate of Water Partial Pressure During Shipping ............. 5-2

5.2.2 Hydrogen Generation From the Reaction of Water with Uranium Metal and

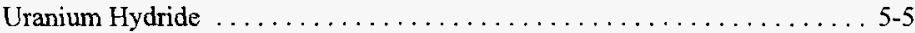

5.2.3 Fission Product Gas Release During Shipping and Staging $\ldots \ldots \ldots \ldots \ldots$ 5-6

5.2.4 Helium Gas Release During Shipping and Staging $\ldots \ldots \ldots \ldots \ldots \ldots .6 .6$

5.2.5 Water Vapor Pressure Increase During Shipping and Staging . . . . . . . . 5-6

5.2.6 Pressurization of a Sealed MCO During Shipping and Staging . . . . . . . . 5-6

5.2 .7 Reduction of Inventory of Reactants $\ldots \ldots \ldots \ldots \ldots \ldots \ldots \ldots \ldots \ldots . . \ldots \ldots$

6.0 GAS GENERATION DURING HOT VACUUM DRYING AND CONDITIONING . 6-1

7.0 GAS GENERATION DURING LONG-TERM STORAGE $\ldots \ldots \ldots \ldots \ldots \ldots \ldots$ 7-1 7.1 RADIOLYTIC GAS GENERATION DURING LONG-TERM STORAGE $\ldots \ldots 7-1$

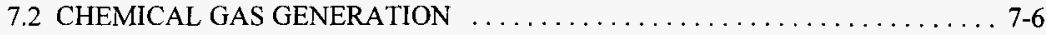

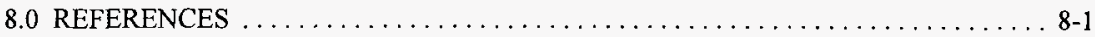




\section{LIST OF TABLES}

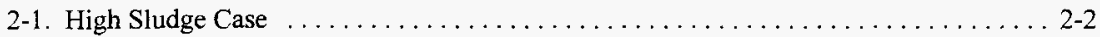

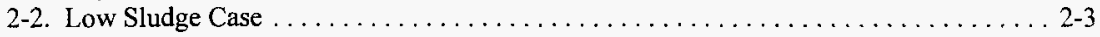

2-3. Radiolytic Gas Generation for a Flooded $\mathrm{MCO} \ldots \ldots \ldots \ldots \ldots \ldots \ldots \ldots \ldots \ldots \ldots$

2-4. Hydrogen Production From Water on Uranium Metal in Flooded MCO . . . . . . . . . 2-9

2-5. Hydrogen Generation from Uranium Hydride in Sludge in a Flooded MCO . . . . . . 2-14

2-6. Pressure Increase for a Flooded MCO With $2.7 \mathrm{~kg}$ Sludge . . . . . . . . . . . 2-18

2-7. Pressure Increase for a Flooded MCO With $16 \mathrm{~kg}$ Sludge $\ldots \ldots \ldots \ldots \ldots \ldots \ldots 20$

2-8. Pressure Increase for a Flooded MCO With $277 \mathrm{~kg}$ Sludge . . . . . . . . . . . . 2-22

3-1. Radiolytic Gas Generation for Uncorroded Fuel in a Drained MCO . . . . . . . . 3-1

3-2. Pressure Increase for a Drained MCO With $2.7 \mathrm{~kg}$ Sludge $\ldots \ldots \ldots \ldots \ldots \ldots \ldots \ldots . \ldots$

3-3. Pressure Increase for a Drained MCO With $16 \mathrm{~kg}$ Sludge $\ldots \ldots \ldots \ldots \ldots \ldots \ldots \ldots$

3-4. Pressure Increase for a Drained MCO With $277 \mathrm{~kg}$ Sludge . . . . . . . . . . . . 3-9

4-1. Hydrogen Generation from Water Reaction with Uranium Metal During CVD . . . . 4-3

5-1. Radiolytic Gas Generation During Shipping and Staging . . . . . . . . . . . 5-1

5-2. Chemical Hydrogen Generation in a Sealed MCO During Shipping and Staging . . . . 5-7

5-3. Pressure Increase for a MCO During Shipping and Staging . . . . . . . . . 5-10

5-4. Pressure Increase for a "Worst-Case" MCO Containing $16 \mathrm{~kg}$ Sludge During Shipping

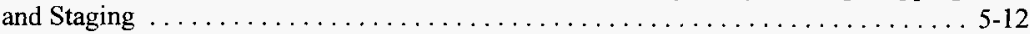

5-5. Pressure Increase for a "Worst-Case" MCO Containing $277 \mathrm{~kg}$ Sludge During Shipping

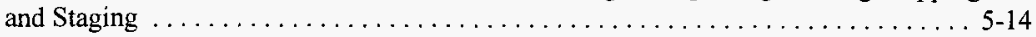

7-1. Water Radiolyzed During Long-term Storage $\ldots \ldots \ldots \ldots \ldots \ldots \ldots \ldots \ldots$ 


\section{LIST OF FIGURES}

2-1. Gas Generation for Uncorroded Fuel in a Flooded MCO ................ 2-7

2-2. Hydrogen from Corroded Metal in a Flooded MCO ................. 2-10

2-3. Hydrogen Generation From Uranium Hydride in a Flooded MCO ........... 2-15

2-4. Pressurization of Flooded-Sealed "Worst-Case" MCO With $2.7 \mathrm{~kg}$ Siudge . . . . . . . . 2-19

2-5. Pressurization of Flooded-Sealed "Worst-Case" MCO With $16 \mathrm{~kg}$ Sludge ........ 2-21

2-6. Pressurization of Flooded MCO With $277 \mathrm{~kg}$ Sludge .................. 2-23

3-1. Radiolytic Gas Generation for Uncorroded Fuel in a Drained MCO ........... 3-2

3-2. Pressurization of a Drained-Sealed "Worst-Case" MCO $2.7 \mathrm{~kg}$ Sludge .......... 3-6

3-3. Pressurization of a Drained-Sealed "Worst-Case" MCO $16 \mathrm{~kg}$ Sludge ........... 3-8

3-4. Pressurization of a Drained-Sealed "Worst Cast" MCO 277 kg Sludge ........... 3-10

4-1. Hydrogen From Water Reaction with Uranium Metal in MCO during CVD ........ 4-4

5-1. Radiolytic Gas Generation During Shipping and Staging $\ldots \ldots \ldots \ldots \ldots \ldots \ldots, 2$

5-2. Hydrogen Generation in the MCO During Shipping and Staging ............ 5-8

5-3. Pressure Increase for a "Worst-Case" MCO Containing $2.7 \mathrm{~kg}$ of Sludge During

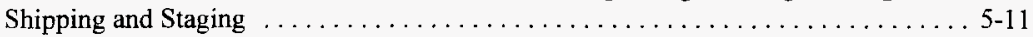

5-4. Pressure Increase for a "Worst-Case" MCO Containing $16 \mathrm{~kg}$ of Sludge During

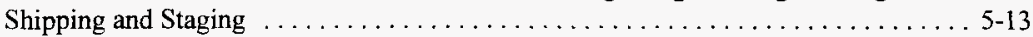

5-5. Pressure for a "Worst-Case" MCO Containing $277 \mathrm{~kg}$ of Sludge During Shipping and

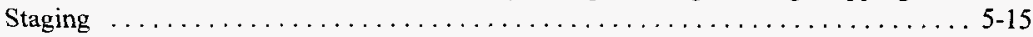

7-1. Water Remaining in MCO During Long-term Storage ............... 7-3

7-2. Water Radiolyzed During Long-term Storage From Sludge Containing $0.5 \mathrm{wt} \%$ Water . 7.5

7-3. Water Radiolyzed During Long-term Storage From Sludge Containing $1.5 \mathrm{wt} \%$ Water . 7-6 
WHC-SD-SNF-TI-028

Revision 0

\section{SPENT NUCLEAR FUEL PROJECT \\ GAS GENERATION FROM N-FUEL IN MULTI-CANISTER OVERPACKS}

\subsection{INTRODUCTION}

During the conversion from wet pool storage to dry storage for spent nuclear fuel at Hanford, gases will be generated from both radiolysis and chemical reactions. The Spent Nuclear Fuel Project (SNF Project) must investigate this phenomenon to determine if the gases can overpressurize the storage containers through either static or dynamic processes. To understand this phenomenon, it is helpful to understand the history of the fuel during manufacture, irradiation in the reactors, and wet pool storage.

Nuclear fuel from the N-Reactor was manufactured by co-extruding uranium metal and zirconium metal into a zirconium-jacketed tube shape. This fuel was manufactured in two separate diameters. The fuel elements were assembled with an inner element placed concentrically within an outer element to make a single fuel assembly. These fuel assemblies were then loaded into horizontal tube channels within the reactor and exposed to various levels of neutron irradiation, as determined by the operating requirements of the reactor.

At discharge, the fuel elements were forced by pressure out of the rear face of the reactor and would fall onto a trampoline within a water pool. Then the fuel elements would slide down a chute and fall into a metal cart, which was used to transport them underwater to the handling and storage facility.

Some cladding failures occurred within the reactor, and many of the assemblies were damaged during the unloading cycle. Each fuel assembly weighs approximately 50 pounds and fell 30-50 feet upon unloading. The kinetic energy was high enough to cause some of the assemblies to split their cladding, fracture, or chip as they slammed into metal structures within the water pool. This damage was of no great concern during plant operations, because the assemblies were typically held for approximately six months before transfer to the Plutonium Uranium Extraction (PUREX) facility for reprocessing.

Some of the assemblies were not reprocessed; however, and were held within the storage pools for up to 25 years. Presently, approximately 100,000 fuel assemblies are still in the K-East and K-West Basins. Approximately $45 \%$ of the outer assemblies and $30 \%$ of the inner assemblies have sustained visible cladding damage and subsequent uranium metal corrosion (WHC 1996a). This corrosion process releases radioactive fission products to the storage pool and could represent an environmental hazard, in the event of a leak from the $\mathrm{K}$ Basins to the Columbia River or into the groundwater table.

The Contractor has been tasked by the U.S. Department of Energy to move the spent nuclear fuel from the K Basins to a dry fuel storage building, which is located approximately ten 
miles from the Columbia River. The Contractor plans to load the fuel into steel transport and storage containers called Multi-canister Overpacks (MCOs). Each MCO will contain five tiers of fuel. Each tier may contain 54 intact fuel assemblies or a scrap basket filled with irregularshaped fuel assembly pieces, which range in length from $1 / 4$-inch to six inches long. The minimal $1 / 4$-inch dimension comes from the requirement that only the scrap retained on a $1 / 4$-inch screen will be stored in an $\mathrm{MCO}$.

Current plans are to load the MCO underwater, transport the MCO to a Cold Vacuum Drying (CVD) Station, weld the lid onto the $\mathrm{MCO}$, drain the bulk water from the $\mathrm{MCO}$, cold vacuum dry the fuel with a starting temperature of $50-75^{\circ} \mathrm{C}$, transport the $\mathrm{MCO}$ to the Canister Storage Building (CSB), hot vacuum dry the fuel, and place the $\mathrm{MCO}$ in long-term interim storage.

In removing, drying, transporting, and storing this fuel, the Contractor needs to determine the potential of this fuel for generating gases that could pressurize the MCO. Hydrogen and oxygen are generated by the radiolysis of water. Hydrogen can also be generated through the reaction of water with uranium metal or uranium hydride in a deoxygenated system. Helium gas evolves from alpha particles. Volatile fission products are released from the oxidation of the fuel. Water vapor exists in equilibrium with other water phases. The higher the temperature, the higher the water vapor partial pressure. At each process step, the gas partial pressures must be summed to calculate the gas pressure in the MCO.

Several independent parameters strongly affect the gas generation rates for corroding uranium. Examples of such parameters are the reactive surface area of the uranium metal, the effect of waters of hydration upon the total water inventory for sludges, and the value chosen for the $\mathrm{G}$ factor of oxide surfaces.

The surface area used in this evaluation is $127,233 \mathrm{~cm}^{2}$ and is based upon a worst-case analysis (WHC 1996b). For this worse case, it is assumed that every fuel assembly position is occupied by a split-end assembly, and that the MCO contained at least one scrap basket filled with 1-inch slices of the fuel assemblies. The surface area may be reduced by administrative measures, and in such cases, the chemical hydrogen production rates will scale proportionately to the exposed area.

It is assumed that the only significant oxides within the $\mathrm{MCO}$ are uranium oxides, which can contain strongly bound surface hydroxides and a monolayer of physically bound water. No waters of hydration are assumed within the oxide interiors. Justification for this assumption is found in Section 5.2.1.

The amount of oxide in the MCO cannot be precisely controlled. Initial estimates ranged from 2.7 to $16 \mathrm{~kg}$. At the time this report was written, a larger estimate of $277 \mathrm{~kg}$ of oxides was recommended. This $277 \mathrm{~kg}$ estimate was intended as an upper bound for purposes of estimating the potential release of particulates. 
This report has consistently included each of these three oxide estimates at each process step. This is intended to provide gas generation rates over a wide oxide range.

In evaluating the in-situ production of gases within the $\mathrm{MCO}$, the discussion is organized by looking at specific process steps. 
WHC-SD-SNF-TI-028

Revision 0

This page is intentionally left blank. 


\subsection{FLOODED MULTI-CANISTER OVERPACK CASE}

\subsection{UNCORRODED FUEL IN A FLOODED MCO}

Uncorroded fuel will generate both hydrogen and oxygen through radiolysis, but will not generate gases chemically. In the absence of getters, these gas mixtures are potentially flammable and detonable.

The radiolytic production of hydrogen within an $\mathrm{MCO}$ is dependent on many variables; such as, the disintegration rate of radionuclides, the disintegration energy, the types of radiation energy, the mass of water, and the self-shielding by the uranium assemblies. Any discussion of a radiolytic hydrogen generation rate is therefore only meaningful when a set of conditions have been specified. J. S. Lan analyzed the radiation energy absorbed by the components of an MCO for the flooded, drained, cold vacuum dried, and hot vacuum dried configurations using the computer code MCNP, Version 3 (WHC 1996c). P. C. Owczarski took Lan's results and modeled the gas generation rates for different $G$ values-for the high sludge cases as represented in Table 2-1 and the low sludge cases as represented in Table 2-2 (Owczarski 1996). Alpha and beta radiation are ignored, as significant levels of these radiation types are not expected to penetrate the Zircaloy cladding. For uncorroded fuel in a flooded $\mathrm{MCO}$, neither the temperature nor the amount of residual sludge significantly influences the amount of hydrogen being generated.

These gases accumulate in the headspace above the water within the MCO. It is estimated that about 44 liters of free headspace is available.

Table 2 1 considers a case where $16 \mathrm{~kg}$ of dry sludge are assumed to be typical of a high sludge process condition. This is not necessarily a bounding sludge condition. Table 2-1 then considers four general cases:

\section{- A Flooded MCO}

For the flooded case, 500 liters is the nominal free volume estimate; but for this particular case, the analyst used 511 liters for the flooded volume. The increase in the hydrogen generation rate is not linear with water volume, and the hydrogen generation rate is not significantly different for the two cases. The sludge is considered to contain $50 \% \mathrm{v} / \mathrm{v}$ water within the sludge. The free water and the sludge are exposed to a common gamma field.

The computer code MCNP, Version 3, was used to calculate the energy deposition within the free water from alpha, beta, and gamma radiation. This calculation shows that gamma radiation deposits $1.1^{*} 10^{-5}$ watts of energy per gram of water. Alpha and beta particles deposit $1.49 * 10^{-5}$ and $1.36^{*} 10^{-4}$ watts per gram, respectively, in the water permeating the sludge. 
Table 2-1. High Sludge Case

N

\begin{tabular}{|c|c|c|c|c|c|c|c|c|c|c|c|}
\hline Mco Condition & Siudge mass & Target $\mathrm{H} 2 \mathrm{O}$ & $\mathrm{Kg}$ & Radiation & Watts/g* & $G$ value & H2 Mol/Sec & Duration Hrs & Days & Years & Total H2 $\mathrm{Mol}$. \\
\hline & Dry & & & & & & & & & & \\
\hline \multirow[t]{11}{*}{ Flooded } & & Flooded Volume 135 gallons & 511 & gamma(high) & $1.10 \mathrm{E}-05$ & $t$ & $5.82 \mathrm{E}-07$ & 64 & 2.6667 & 0.007306 & $1.34 \mathrm{E}-01$ \\
\hline & & Flooded Volume 135 gallons & 511 & gamma (Med) & $1.10 \mathrm{E}-05$ & 0.3 & $1.75 E-07$ & 64 & 2.6667 & 0.007306 & $4.02 \mathrm{E}-02$ \\
\hline & & Flooded Volume 135 gallons & 511 & gamma (Low) & 1.10E-05 & 0.1 & $5.82 E-08$ & 64 & 2.6667 & 0.007306 & 1.34E-02 \\
\hline & 16 & U02 Sludge $50 \% \mathrm{H} 20 \mathrm{v} / \mathrm{N}$ & 1.46 & alpha (s) & 1.49E-06 & 3 & $6.77 \mathrm{E}-09$ & 64 & 2.6667 & 0.007306 & \\
\hline & 16 & U02 Sludge $50 \% \mathrm{H} 2 \mathrm{O} \mathrm{WN}$ & 1.46 & beta (b) & $1.36 \mathrm{E}-04$ & 1.4 & $2.88 E-08$ & 64 & 2.6667 & 0.007306 & \\
\hline & 16 & LO2 Sludge $50 \% \mathrm{H} 2 \mathrm{O} \mathrm{VN}$ & 1.46 & gamma(high) & 1.10E-05 & 20 & $3.33 \mathrm{E}-08$ & 64 & 2.6667 & 0.007306 & $1.59 \mathrm{E}-02$ \\
\hline & 16 & U02 Sludge $50 \% \mathrm{H} 2 \mathrm{O} \mathrm{v} / \mathrm{N}$ & 1.46 & garnma (Med) & 1.10E-05 & 1 & $1.66 E-09$ & 64 & 2.6667 & 0.007306 & 8.57E-03 \\
\hline & 16 & U02 Sludge $50 \% \mathrm{H} 2 \mathrm{O}$ w/v & 1.46 & gamma (Low) & $1.10 \mathrm{E} \cdot \mathrm{-05}$ & 0.1 & $1.66 \mathrm{E}-10$ & 64 & 2.6667 & 0.007306 & 8.23E-03 \\
\hline & & & & & & total, high & 6.5TE-07 & & & & 1.50E-01 \\
\hline & & Total H2, moles & 28469.992 & & & total, med & 2.12E-07 & & & & $4.88 E-02$ \\
\hline & & & & & & 1otal, low & 9.40E-08 & & & & $2.16 E-02$ \\
\hline \multirow[t]{11}{*}{ Drained } & & 14 Liters & 14 & gamma(high) & $1.20 \mathrm{E}-05$ & 1 & $1.74 \mathrm{E}-08$ & 2 & 0.083333 & 0.000228 & $1.25 \mathrm{E}-04$ \\
\hline & & 14 Liters & 14 & gamima (Med) & $1.20 \mathrm{E}-05$ & 0.3 & $5.22 E-09$ & 2 & 0.083333 & 0.000228 & $3.76 E-05$ \\
\hline & & 14 Liters & 14 & gamma (Low) & 1.20E-05 & 0.1 & 1.74E-00 & 2 & 0.083333 & 0.000228 & $1.25346 \mathrm{E}-5$ \\
\hline & 16 & UO2 Sludge $50 \% \mathrm{H} 2 \mathrm{O} \mathrm{v} / \mathrm{V}$ & 1.46 & alpha (s) & 1.49E-05 & 3 & $1.14 \mathrm{E}-09$ & 2 & 0.083333 & 0.000228 & \\
\hline & 16 & UO2 Siudge $50 \% \mathrm{H} 2 \mathrm{O} \mathrm{v} / \mathrm{v}$ & 1.46 & beta (b) & $1.36 \mathrm{E}-04$ & 14 & 4.86E-09 & 2 & 0.083333 & 0.000228 & \\
\hline & 16 & UO2 Sludge $50 \% \mathrm{H} 2 \mathrm{O}$ v/v & 1.46 & gamma(high) & 1.20E-05 & 20 & 4.86E-09 & 2 & 0.083333 & 0.000228 & $5.17 \mathrm{E}-04$ \\
\hline & 16 & UO2 Sludge $50 \% \mathrm{H} 2 \mathrm{O}$ v/v & 1.46 & gamma (Med) & $1.20 \mathrm{E}-05$ & 1 & $6.13 \mathrm{E}-09$ & 2 & 0.083333 & 0.000228 & $2.69 \mathrm{E}-04$ \\
\hline & 16 & UO2 Sludge $50 \% \mathrm{H} 2 \mathrm{O} \mathrm{v} / \mathrm{v}$ & 1.46 & gamma (Low) & 1.20E-05 & 0.1 & $3.06 E-10$ & 2 & 0.083333 & 0.000228 & $2.57 \mathrm{E}-04$ \\
\hline & & & & & & total, high & 8.93E-08 & & & & $2.12366 \bar{E}-04$ \\
\hline & & Total H2, moles & 858.88078 & & & total, med & 4.26E-08 & & & & 6.3008 E-04 \\
\hline & & & & & & total, low & 3.75E-08 & & & & 5.8954 E-04 \\
\hline Cold Vacuum Dried & & Thin Monomolecular Film & $2.83 E-05$ & gamma(high) & $6.90 \mathrm{E}-06$ & 20 & $4.0471 \mathrm{E}-13$ & 17520 & 730 & 2 & $2.22118 \mathrm{E}-05$ \\
\hline \multirow[t]{10}{*}{82 Year Staging } & & Thin Monomolecular Film & $2.83 E-05$ & gamma (Med) & $6.90 \mathrm{E}-06$ & 1 & $2.0235 \mathrm{E}-14$ & 17520 & 730 & 2 & $1.11811 \mathrm{E}-06$ \\
\hline & & Thin Monomolecular Film & $2.83 \mathrm{E}-05$ & gamma (Low) & $6.90 \mathrm{E}-06$ & 0.1 & 2.0235 E-15 & 17520 & 730 & 2 & $1.11847 \mathrm{E}-7$ \\
\hline & 16 & U02 Sludge $10 \% \mathrm{H2O} \mathrm{viv}$ & $1.62 \mathrm{E}-01$ & alpha (s) & $1.61 \mathrm{E}-05$ & 3 & $8.13 E-10$ & 17520 & 730 & 2 & \\
\hline & 16 & UO2 Sludge $10 \% \mathrm{H} 2 \mathrm{O} \mathrm{v} / \mathrm{v}$ & 1.62E-01 & beta (b) & 1.47E-04 & 1.4 & 3.45E-09 & 17520 & 730 & 2 & \\
\hline & 16 & UO2 Sludge $10 \% \mathrm{H} 2 \mathrm{O} \mathrm{v} / \mathrm{v}$ & $1.62 E-01$ & gemmafhigh) & $1.61 \mathrm{E}-05$ & 20 & 5.42E-09 & 17520 & 730 & 2 & $5.28 \mathrm{E}-01$ \\
\hline & 16 & UO2 Sludge $10 \% \mathrm{H} 2 \mathrm{O}$ vN & $1.62 \mathrm{E}-01$ & gamma (Med) & 1.47E-04 & 1 & 2.47E-09 & 17520 & 730 & 2 & 3.73E-01 \\
\hline & 16 & UO2 Sludge $10 \% \mathrm{H} 2 \mathrm{O} \mathrm{VN}$ & $1.62 \mathrm{E}-01$ & gamma (Low) & 1.47E-04 & 0.1 & $2.47 \mathrm{E}-10$ & 17520 & 730 & 2 & 2.54E-01 \\
\hline & & & & & & total, high & $9.69 E-09$ & & & & $5.28 \mathrm{E}-01$ \\
\hline & & Total H2, moles & 9 & & & total, med & 6.74E-09 & & & & 3.73E-01 \\
\hline & & & & & & total, low & 4.51E-09 & & & & 2.54E-01 \\
\hline Hot Vacusm & & Thin Monomolecular Ftim & $2 . B 3 E-5$ & gamma(high) & $6.90 \mathrm{E}-06$ & 20 & 4.05E.13 & 657000 & 27375 & 75 & 9.18E-05 \\
\hline \multirow[t]{12}{*}{ CSB Storage } & & Thin Monomolecular Film & $2.83 \mathrm{E}-5$ & gamma (Med) & $6.90 \mathrm{E}-06$ & +1 & $2.02 E-14$ & 657000 & 27375 & 75 & $4.72 E-06$ \\
\hline & & Thin Monomolecular Film & $2.83 \mathrm{E}-5$ & garnma (Low) & $6.90 \mathrm{E}-06$ & 0.1 & $2.02 E-15$ & 657000 & 27375 & 75 & $4.73 E-07$ \\
\hline & 16 & UO2 Sludge $5 \% \mathrm{H} 2 \mathrm{O} \mathrm{w}$ & $1.80 \mathrm{E}-01$ & alpha (s) & $1.62 \mathrm{E}-05$ & 3 & $4.05 E-40$ & 657000 & 27375 & 75 & \\
\hline & 16 & UO2 Sludge $5 \% \mathrm{H} 2 \mathrm{O} \mathrm{v} / \mathrm{v}$ & $8.04 \mathrm{E}-02$ & beta (b) & 1.48E-04 & 1.4 & $1.72 \mathrm{E} .09$ & 657000 & 27375 & 75 & \\
\hline & 16 & $\mathrm{UO} 2$ Sludge $5 \% \mathrm{H} 2 \mathrm{ONN}$ & B. $04 \mathrm{E}-02$ & gamma(high) & $6.90 \mathrm{E}-08$ & 20 & 1.15E-09 & 657000 & 27375 & 75 & $2.22 E+\infty$ \\
\hline & 16 & UO2 Sludge $5 \% \mathrm{H} 2 \mathrm{O} \mathrm{v} / \mathrm{V}$ & $8.04 \mathrm{E}-02$ & gamma (Med) & $6.90 \mathrm{E}-08$ & 1 & $5.75 \mathrm{E}-11$ & 657000 & 27375 & 75 & $2.09 E+00$ \\
\hline & 16 & $\mathrm{UO} 2$ Sludge $5 \% \mathrm{H} 2 \mathrm{O} \mathrm{vN}$ & 8.04E-02 & gamma (low) & $6.90 \mathrm{E}-08$ & 0.1 & $5.75 E-12$ & 657000 & 27375 & 75 & $2.08 E+00$ \\
\hline & & & & & & total, high & $3.28 \mathrm{E}-09$ & & & & $2.22 \mathrm{E}+00$ \\
\hline & & Total H2, moles & 4.4683506 & & & total, med & 2.18E-09 & & & & $2.09 \mathrm{E}+00$ \\
\hline & & & & & & total, low & $2.13 E-09$ & & & & $2.08 E+00$ \\
\hline & & & & & & & & & & & * *includes alpha + \\
\hline & & & & \multicolumn{4}{|c|}{ Energy absorbed by $\mathrm{H} 20$} & & & & beta in sludge rows \\
\hline
\end{tabular}


Table 2-2. Low Sludge Case

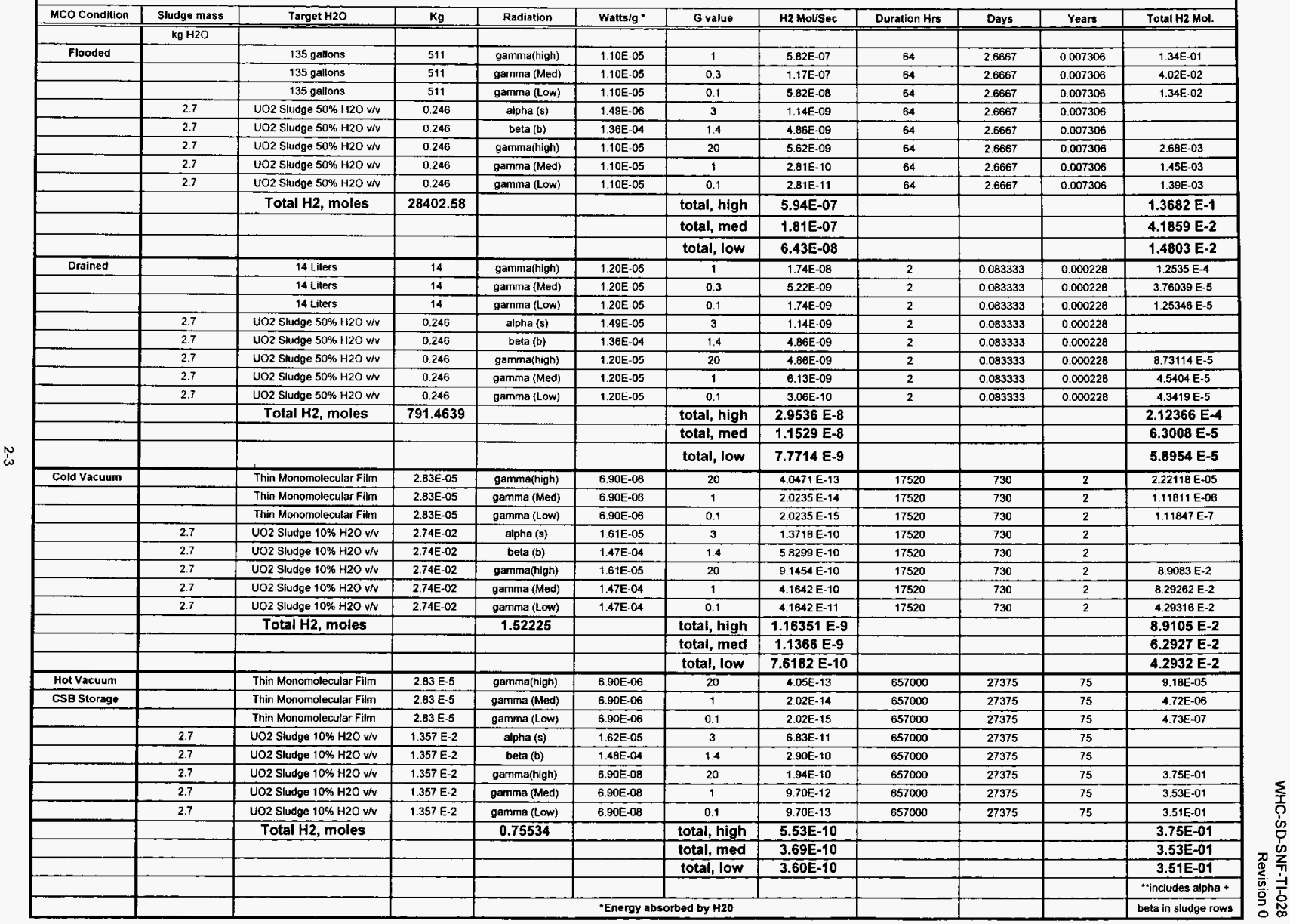


$G$ values are defined as the number of product molecules formed by the radiolysis process per 100 electron volts (ev) of radiation energy. $G$ values ranging from 0.3 to 1.0 have been reported for the interaction of gamma rays with free water. To be conservative, the value of 1.0 was chosen for this analysis.

$\mathrm{G}$ values ranging from 10 to 40 have been reported for the interaction of gamma radiation with water adsorbed on oxide surfaces (Owczarski 1996). No theoretical explanation can be offered at this time for these rather high $\mathrm{G}$ values. Since they were experimentally determined, their authenticity is accepted, and a fairly typical value of 20 was chosen for this analysis.

Using the energy deposition rate calculated by Lan and the $G$ values from Owczarski, the hydrogen generation rate can be calculated. The radiolytic oxygen generation rate is assumed to be one-half of the hydrogen generation rate.

\section{- A Drained MCO}

For a drained $\mathrm{MCO}$, it is assumed that $14 \mathrm{~kg}$ of water represent a reasonable heel for the $16 \mathrm{~kg}$ of sludge. The sludge is still permeated with water at the $50 \% \mathrm{v} / \mathrm{v}$ ratio. All other conditions were similar to the flooded case.

\section{- A Cold Vacuum Dried MCO}

Lacking experimental data, there are differences of opinion as to the amount of sludge within the $\mathrm{MCO}$, and the amount of free water that will be retained within the sludge and upon oxide surfaces. Sixteen $\mathrm{kg}$ of sludge was arbitrarily defined as a relatively high, but not necessarily bounding, amount of sludge for a process case.

The amount of water that is retained after CVD will in some measure be proportional to the amount of sludge being dried, because of diffusion and the heat transfer phenomena. No experimental data is available for water retention by $\mathrm{UO}_{2}$, so data from $\mathrm{PuO}_{2}$ will be used as a basis, until characterization data is available (Rasmussen 1969). Rasmussen, quoting data from NUMEC-P-90 (page 17), discusses water absorption rather than water retention; but assuming the phenomenon is reversible, one may calculate a suitable water retention value.

Rasmussen shows that when pure plutonium dioxide is calcined at $350{ }^{\circ} \mathrm{C}$ for $1 / 2$ hour, and subsequently exposed to air at relative humidity (RH) less than $20 \%$ at $25{ }^{\circ} \mathrm{C}$, less than 5 grams of water are absorbed per $\mathrm{kg}$. This is $1 / 2 \% \mathrm{w} / \mathrm{w}$, but by using the appropriate density ratios, a value of $6 \% \mathrm{v} / \mathrm{v}$ can be calculated. This value was increased to $10 \% \mathrm{v} / \mathrm{v}$ for the sake of conservatism.

The gamma energy deposition rate is lower for a thin film of water because of decreased linear energy absorption coefficients within a thin film. 


\section{- A Hot Vacuum Dried MCO}

For a hot vacuum dried $\mathrm{MCO}$, it was assumed the residual moisture is $0.5 \% \mathrm{w} / \mathrm{w}$. Again, a reduction can be seen in the linear absorption coefficients for gamma energy in the water retained in the sludge.

\subsubsection{Calculation of Radiolytic Gas Generation Rates}

\section{- Initial data}

From Table 2-1:

Mass dry sludge $=16 \mathrm{~kg}$

Volume water $=511$ liters

Energy deposition rate $=1.1 \mathrm{E}-5$ watts/gram water

Conservative $\mathrm{G}$ value $=1$ molecule $\mathrm{H}_{2} / 100$ ev energy

\section{- Example Calculation}

Flooded Volume:

$\mathrm{H}_{2}$ rate $\mathrm{moles} / \mathrm{sec}=$

(1.10E-05 watts/gram $\left.\mathrm{H}_{2} \mathrm{O}\right) *\left(511,000\right.$ grams $\left.\mathrm{H}_{2} \mathrm{O}\right) *\left(6.242^{*} 10^{18}\right.$ ev/watt-sec. $) *$

( 1 molecule $\left.\mathrm{H}_{2} / 100 \mathrm{ev}\right) /\left(6.023 * 10^{23}\right.$ molecules $\mathrm{H}_{2} /$ gmole)

$=5.8254 \mathrm{E}-07 \mathrm{H}_{2}$ gmoles $/ \mathrm{sec}$.

\section{- Sludge}

$16 \mathrm{~kg} / 5.47 \mathrm{grams} / \mathrm{ml}=2,925 \mathrm{mls}$

Now, if $50 \%$ of that volume is water, there are $1,462.5$ grams of water in $16 \mathrm{~kg}$ of sludge.

so,

(1.49E-05 watts(alpha)/gram $\left.\mathrm{H}_{2} \mathrm{O}\right) *\left(1462.5\right.$ grams $\left.\mathrm{H}_{2} \mathrm{O}\right) *\left(6.242 * 10^{18}\right.$ ev/watt-sec.)

* (3 molecules $\left.\mathrm{H}_{2} / 100 \mathrm{ev}\right) /\left(6.023 * 10^{23}\right.$ molecules $\mathrm{H}_{2}$ /gmole $)$

$=6.773 \mathrm{E}-9$ gmoles $\mathrm{H}_{2} / \mathrm{sec}$ from alpha radiation in sludge from Table 2-1, the beta contribution is $2.878 \mathrm{E}-8$ gmoles $\mathrm{H}_{2} / \mathrm{sec}$, and using the conservative $\mathrm{G}$ value of 20 for gamma on an oxide surface, the sludge gamma contribution is $3.3282 \mathrm{E}-8$ gmoles $\mathrm{H}_{2} / \mathrm{sec}$. 
The total $\mathrm{H}_{2}$ production is the sum of the hydrogen generation in the flooded volume and in the sludge:

$$
\begin{aligned}
& \mathrm{H}_{2}=5.8254 \mathrm{E}-07+6.773 \mathrm{E}-9+2.878 \mathrm{E}-8+3.3282 \mathrm{E}-8 \\
& =6.513 \mathrm{E}-07 \text { gmoles } / \mathrm{sec} \\
& =2.35 \mathrm{E}-3 \mathrm{gmoles} / \mathrm{hr}
\end{aligned}
$$

Similar rates can be calculated for the $2.7 \mathrm{~kg}$ sludge case and the $277 \mathrm{~kg}$ sludge case.

Table 2-3 and Figure 2-1 were generated by multiplying these rates (for hydrogen), and one half of these rates (for oxygen), by the number of elapsed hours.

Table 2-3. Radiolytic Gas Generation for a Flooded MCO.*

\begin{tabular}{|c|c|c|c|c|c|c||}
\hline \multirow{2}{*}{$\begin{array}{c}\text { Time } \\
\text { Hours }\end{array}$} & \multicolumn{2}{|c|}{$\mathbf{2 . 7}$ kg Sludge } & \multicolumn{2}{c|}{ 16 kg Sludge } & \multicolumn{2}{c|}{ 277 kg Sludge } \\
\cline { 2 - 7 } & Oxygen & Hydrogen & Oxygen & Hydrogen & Oxygen & Hydrogen \\
\hline 1 & $1.069 \mathrm{E}-3$ & $2.139 \mathrm{E}-3$ & $1.172 \mathrm{E}-3$ & $2.345 \mathrm{E}-3$ & $2.145 \mathrm{E}-3$ & $4.290 \mathrm{E}-3$ \\
\hline 5 & $5.347 \mathrm{E}-3$ & $1.069 \mathrm{E}-2$ & $5.862 \mathrm{E}-3$ & $1.172 \mathrm{E}-2$ & $1.073 \mathrm{E}-2$ & $2.145 \mathrm{E}-2$ \\
\hline 10 & $1.069 \mathrm{E}-2$ & $2.139 \mathrm{E}-2$ & $1.172 \mathrm{E}-2$ & $2.345 \mathrm{E}-2$ & $2.145 \mathrm{E}-2$ & $4.290 \mathrm{E}-2$ \\
\hline 20 & $2.139 \mathrm{E}-2$ & $4.278 \mathrm{E}-2$ & $2.345 \mathrm{E}-2$ & $4.690 \mathrm{E}-2$ & $4.290 \mathrm{E}-2$ & $8.580 \mathrm{E}-2$ \\
\hline 30 & $3.208 \mathrm{E}-2$ & $6.416 \mathrm{E}-2$ & $3.517 \mathrm{E}-2$ & $7.034 \mathrm{E}-2$ & $6.435 \mathrm{E}-2$ & $1.287 \mathrm{E}-1$ \\
\hline 40 & $4.278 \mathrm{E}-2$ & $8.555 \mathrm{E}-2$ & $6.900 \mathrm{E}-2$ & $9.379 \mathrm{E}-2$ & $8.580 \mathrm{E}-2$ & $1.716 \mathrm{E}-1$ \\
\hline 50 & $5.347 \mathrm{E}-2$ & $1.069 \mathrm{E}-1$ & $5.862 \mathrm{E}-2$ & $1.172 \mathrm{E}-1$ & $1.073 \mathrm{E}-1$ & $2.145 \mathrm{E}-1$ \\
\hline 60 & $6.416 \mathrm{E}-2$ & $1.283 \mathrm{E}-1$ & $7.034 \mathrm{E}-2$ & $1.407 \mathrm{E}-1$ & $1.287 \mathrm{E}-1$ & $2.574 \mathrm{E}-1$ \\
\hline 70 & $7.486 \mathrm{E}-2$ & $1.497 \mathrm{E}-1$ & $8.207 \mathrm{E}-2$ & $1.641 \mathrm{E}-1$ & $1.501 \mathrm{E}-1$ & $3.003 \mathrm{E}-1$ \\
\hline
\end{tabular}

* Units are moles of gas. 
Figure 2-1. Gas Generation for Uncorroded Fuel in a Flooded MCO.

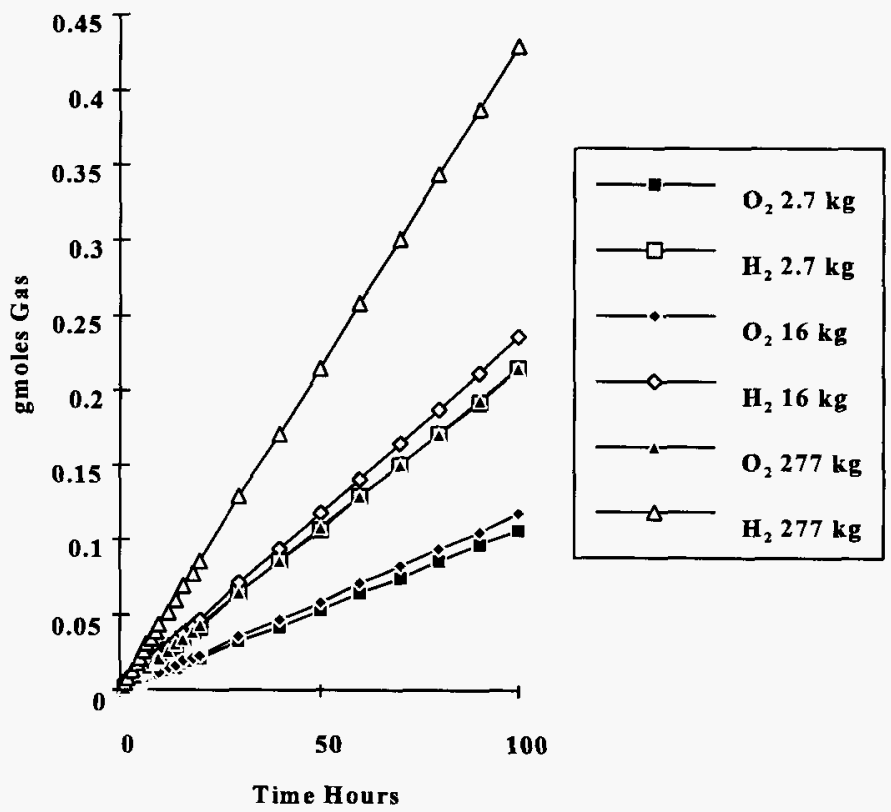

The data in Table 2-3 and Figure 2-1 show that the radiolytic gas generation rate is essentially linear with time.

For a flooded $\mathrm{MCO}$, the large amount of liquid water is the main source of radiolytic gases. Small amounts of sludge do not strongly affect the radiolytic gas generation rates.

For the $277 \mathrm{~kg}$ case, approximately 42 hours are required to reach a flammable mixture in the headspace in the MCO. This would indicate that a maximum flooded sealed duration would be 21 hours (half the time to reach flammable concentration per packaging and shipping criteria). This is an unacceptably short duration for a sealed package, unless a reliable, positive means to vent and dilute the MCO headspace contents is in place at all times. 


\subsection{CORRODED FUEL IN A FLOODED MCO}

\subsubsection{Radiolytic Gases}

The radiolytic gas generation rate for corroded fuel in a flooded $\mathrm{MCO}$ is approximately the same as for uncorroded fuel. This rate is not significant, when compared to the rate for chemically produced hydrogen from corroded fuel assemblies.

\subsubsection{Chemically Produced Hydrogen}

Hydrogen is chemically produced from water under strongly reducing conditions; in this case, by contact with uranium metal in the absence of strong oxidizers such as oxygen gas.

The liquid pool water is in direct contact with the atmosphere and is initially oxygenated. Oxygen in liquid water is not quite as effective in reducing the water reaction rate with uranium metal as oxygen in air. It is possible, therefore, that small amounts of hydrogen may be emitted from the reaction of oxygenated liquid water.

For the sake of simplicity, the possibility of a hydrogen production rate from oxygenated water is ignored, and only the hydrogen production from deoxygenated water was tallied.

If the MCO is sealed for shipment to the CVD station, the residual oxygen will react with exposed uranium surfaces, and the system will eventually become deoxygenated. In the absence of oxygen, hydrogen will be produced chemically:

$$
\mathrm{U}+2 \mathrm{H}_{2} \mathrm{O}=\mathrm{UO}_{2}+2 \mathrm{H}_{2}
$$

The rate is calculated as follows:

$$
\begin{aligned}
& \text { Moles } \mathrm{O}_{2} \text { fixed } / \mathrm{hr} / \mathrm{cm}^{2}= \\
& (10)^{*} 10^{(7.634 \cdot 3016 / \mathrm{T})}\left(\mathrm{mg} \mathrm{O} \mathrm{O}_{2} / \mathrm{cm}^{2} / \mathrm{hr} / 32000 \mathrm{mg} / \mathrm{mole}\right)
\end{aligned}
$$

Moles $\mathrm{H}_{2} / \mathrm{hr} / \mathrm{cm}^{2}=$

$$
\begin{aligned}
& \left(\text { Moles } \mathrm{O}_{2} / \mathrm{hr} / \mathrm{cm}^{2}\right) * 2 \text { moles of } \mathrm{H}_{2} / \text { mole of } \mathrm{O}_{2} \\
& =2 * 10^{*} 10^{(7.634-3016 / \mathrm{T})} / 32000
\end{aligned}
$$

The hydrogen production rate from the chemical reaction rate of water with uranium metal can now be calculated and is found in Table 2-4 and Figure 2-2. 
Table 2-4. Hydrogen Production From Water on Uranium Metal in Flooded MCO.

\begin{tabular}{|c|c|c|c|c|c||}
\hline \multirow{2}{*}{ Time Hours } & \multicolumn{5}{|c|}{ Temp $\left({ }^{\circ} \mathbf{C}\right)$} \\
\cline { 2 - 6 } & $\mathbf{1 0}$ & $\mathbf{2 0}$ & $\mathbf{5 0}$ & $\mathbf{7 5}$ & $\mathbf{1 0 0}$ \\
\hline 1 & $6.01 \mathrm{E}-07$ & $1.39 \mathrm{E}-06$ & $1.25 \mathrm{E}-05$ & $5.85 \mathrm{E}-05$ & $2.23 \mathrm{E}-04$ \\
\hline 5 & $3.00 \mathrm{E}-06$ & $6.93 \mathrm{E}-06$ & $6.25 \mathrm{E}-05$ & $2.93 \mathrm{E}-04$ & $1.11 \mathrm{E}-03$ \\
\hline 10 & $6.01 \mathrm{E}-06$ & $1.39 \mathrm{E}-05$ & $1.25 \mathrm{E}-04$ & $5.85 \mathrm{E}-04$ & $2.23 \mathrm{E}-03$ \\
\hline 20 & $1.20 \mathrm{E}-05$ & $2.77 \mathrm{E}-05$ & $2.50 \mathrm{E}-04$ & $1.17 \mathrm{E}-03$ & $4.45 \mathrm{E}-03$ \\
\hline 30 & $1.80 \mathrm{E}-05$ & $4.16 \mathrm{E}-05$ & $3.75 \mathrm{E}-04$ & $1.76 \mathrm{E}-03$ & $6.68 \mathrm{E}-03$ \\
\hline 40 & $2.40 \mathrm{E}-05$ & $5.55 \mathrm{E}-05$ & $5.00 \mathrm{E}-04$ & $2.34 \mathrm{E}-03$ & $8.90 \mathrm{E}-03$ \\
\hline 50 & $3.00 \mathrm{E}-05$ & $6.93 \mathrm{E}-05$ & $6.25 \mathrm{E}-04$ & $2.93 \mathrm{E}-03$ & $1.11 \mathrm{E}-02$ \\
\hline 60 & $3.60 \mathrm{E}-05$ & $8.32 \mathrm{E}-05$ & $7.50 \mathrm{E}-04$ & $3.51 \mathrm{E}-03$ & $1.34 \mathrm{E}-02$ \\
\hline 70 & $4.20 \mathrm{E}-05$ & $9.71 \mathrm{E}-05$ & $8.75 \mathrm{E}-04$ & $4.10 \mathrm{E}-03$ & $1.56 \mathrm{E}-02$ \\
\hline \hline
\end{tabular}

* Units are moles of hydrogen $/ \mathrm{cm}^{2}$. 
Figure 2-2. Hydrogen from Corroded Metal in a Flooded MCO.

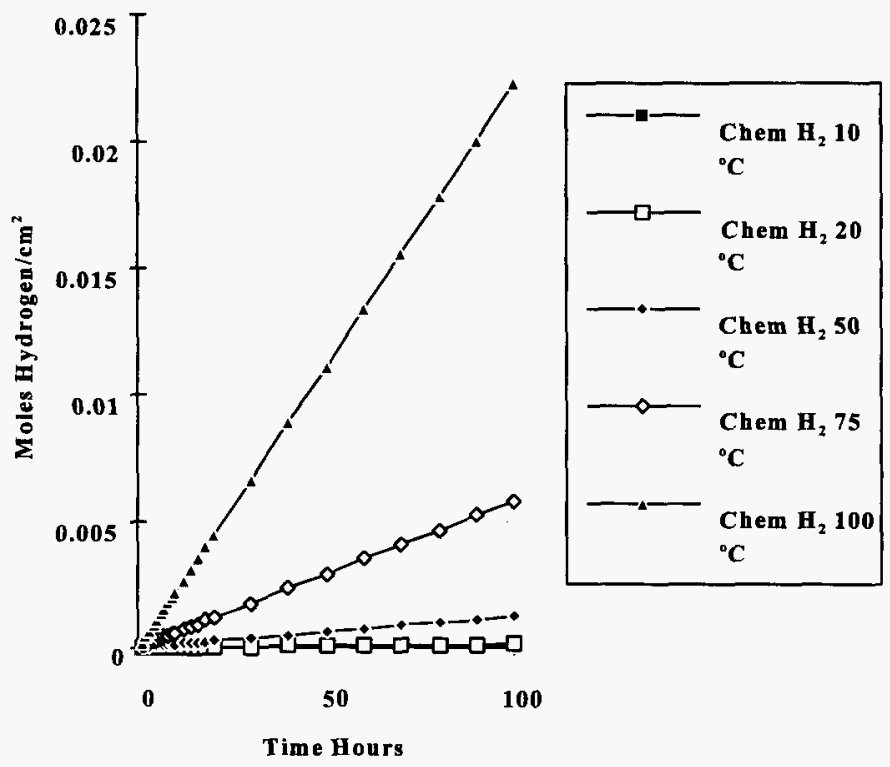

\subsubsection{Hydrogen Generation from Reaction of Hydrides}

According to M. Baker, the aqueous corrosion product on uranium metal consists of a mixture of uranium oxides and uranium hydride (Baker 1966). The percentage of hydride is estimated to vary from $2 \%$ to $9 \%$ depending on the reaction conditions. The percentage of hydride rises with relative humidity and decreases with oxygen concentration. For corrosion products formed in an open pool, the hydride percentage is conservatively estimated to be $9 \%$.

This finely divided black powder has a surface area of $30 \mathrm{~m}^{2} / \mathrm{g}$ as measured with the krypton B.E.T. method. X-ray powder crystallography showed a $\mathrm{UO}_{2}$-type structure and a lattice spacing corresponding to $\mathrm{UO}_{2+\mathrm{x}}$ where $\mathrm{x}$ varied from 0.0 to 0.1 . Because of the small crystallite size, a diffuse pattern was obtained. Minor products comprising less than $10-15 \%$ of the total would not be distinguishable. 
The reaction rate of uranium hydride within the natural corrosion product with water is not known. The very fact that it survives long enough to be measured in the laboratory is an indicator that it is not very reactive at $10^{\circ} \mathrm{C}$.

Pure uranium hydride reacts rapidly with water at room temperature, although the reaction becomes very slow within a few minutes and after 2 weeks, only $15-20 \%$ reaction has occurred. At $100{ }^{\circ} \mathrm{C}, 80 \%$ reaction was achieved within 40 hours.

Solid surface reactions are typically first order with respect to surface area. If a constant relationship between the molar-specific surface area and $\mathrm{N}$ (the number of moles of uranium hydride) is assumed, then, for first order reactions:

$$
\mathrm{dn} / \mathrm{dt}=-\lambda * \mathrm{~N}
$$

and

$$
\mathrm{N}=\mathrm{No}^{*} \operatorname{Exp}\left(-\lambda^{*} \mathrm{t}\right)
$$

$\lambda$ can be defined from:

$$
\operatorname{Ln}(\mathrm{N} / \mathrm{No})=-\lambda * t
$$

so

$$
\lambda 1=-\operatorname{Ln}(0.8) / 336=6.64118^{*} 10^{-4}
$$

and

$$
\lambda 2=-\operatorname{Ln}(0.2) / 40=4.02359 * 10^{-2}
$$

Now $\lambda$ is the fraction that reacts in one hour and, therefore, is a reaction rate. The Arrhenius reaction rate can then be described by:

$$
\text { Rate }=A_{0} * \operatorname{Exp}(\Delta \mathrm{G} / \mathrm{RT})
$$

so

$$
\begin{aligned}
& 6.64118^{*} 10^{-4}=A 0^{*} \operatorname{Exp}\left(\Delta \mathrm{G} / \mathrm{R}^{*} 298\right) \\
& 4.02359^{*} 10^{-2}=A \mathrm{Ao}^{*} \operatorname{Exp}\left(\Delta \mathrm{G} / \mathrm{R}^{*} 373\right)
\end{aligned}
$$

and solved simultaneously,

$$
\lambda=10^{(5.69034-2644.11 / \mathrm{T})}
$$


WHC-SD-SNF-TI-028

Revision 0

where:

$\lambda$ is the fraction of $\mathrm{UH}_{3}$ reacted per hour

$\mathrm{T}$ is the temperature in ${ }^{\circ} \mathrm{K}$.

Note: The above mathematical treatment is essentially correct for calculating the rate of reaction of uranium hydride with water. When the basic matrix is changed from hydride to oxide, the diffusion rates of water are slower and the resulting reaction rates will slow. There is reason to believe that the hydrogen production from oxides containing small amounts of hydride will be slower than calculated by the above model; however, since we do not have experimental reaction rates of small amounts of hydride embedded in large amounts of oxides, and since these rates are conservative from a safety viewpoint, they will be used.

The reaction of uranium hydride with water is:

$$
2 \mathrm{UH}_{3}+4 \mathrm{H}_{2} \mathrm{O}=2 \mathrm{UO}_{2}+7 \mathrm{H}_{2}
$$

Now the hydrogen generation rate from the reaction of uranium hydride with water can be calculated for different temperatures.

First, the case of uranium hydride in the corrosion product attached to uranium metal is examined. This hydride is formed by reaction of uranium metal with nascent hydrogen formed at the metal surface. It exists for some time period and then reacts with either oxygen or water.

If it reacts with oxygen, only water is generated as a product and no hydrogen is emitted. If it reacts with water, hydrogen is emitted as a product and the question is whether this hydrogen should be counted as a gas contributing to the pressurization of the MCO. It should not be counted as a pressurizing gas for the following reason. The initial reaction rate equations describe all of the hydrogen that is being released from water. Part of that hydrogen is trapped temporarily as hydride and is then released at a later time. The hydrogen from hydride in the metal corrosion film is, therefore, already accounted for and is not a new source of hydrogen.

The next question is whether sludge, which is not attached to the metal and is added to the $\mathrm{MCO}$, contains significant quantities of hydrides, and whether hydrogen released from the sludge should be considered a source of pressurizing gas.

To answer this question, the history of the sludge in the canisters must be considered. The sludge in the canisters has formed continuously since the last fuel segregation campaign in 1983-84. 
The rate of formation of uranium hydride is the rate of corrosion multiplied by 0.09 .

$$
+\mathrm{dn} / \mathrm{dt}=\mathrm{k} 1 * \text { Surface Area } * 0.09=\mathrm{K}
$$

Where $\mathrm{kl}$ is the molar corrosion rate constant

The decrease in hydride due to reaction with water

$$
-d n / d t=\lambda^{*} n \text { where } n \text { is the number of gmoles of hydride }
$$

so the net change in $\mathbf{n}$ is:

$$
\text { net } \mathrm{dn} / \mathrm{dt}=\mathrm{K}-\lambda^{*} \mathrm{n}
$$

this can be rearranged algebraically to give

$$
\mathrm{dn} /(\mathrm{K}-\lambda * \mathrm{n})=\mathrm{dt}
$$

upon integrating

$$
\left(K-\lambda^{*} n\right) /\left(K-\lambda^{*} n_{o}\right)=e^{\lambda^{*}}
$$

Now since $n_{o}=o$

$$
\begin{aligned}
& \left(\mathrm{K}-\lambda^{*} \mathrm{n}\right) / \mathrm{K}=\mathrm{e}^{\lambda^{*} \mathrm{t}} \\
& 1-\lambda^{*} \mathrm{n} / \mathrm{K}==\mathrm{e}^{\lambda^{*} \mathrm{t}} \\
& \lambda^{*} \mathrm{n}=\mathrm{K}\left(1-\mathrm{e}^{\lambda^{*} t}\right) \\
& \text { or } \lambda^{*} \mathrm{n} / \mathrm{K}=1-\mathrm{e}^{-\lambda^{*} \mathrm{t}}
\end{aligned}
$$

Now since in this case

$$
\begin{aligned}
& 1-\mathrm{e}^{-\lambda * t}= \\
& 1-\mathrm{e}^{-(10(5.69034-2644.11 / 283.16) * 13 \mathrm{Y} * 365.25 * 24} \\
& =1
\end{aligned}
$$

the system is in equilibrium and

$$
-\mathrm{dn} / \mathrm{dt}=\lambda^{*} \mathrm{n}=+\mathrm{dn} / \mathrm{dt}
$$


Now the rate of $\mathrm{UH}_{3}$ reaction with water to produce hydrogen at $10^{\circ} \mathrm{C}$ is:

$$
\begin{aligned}
& \lambda * \mathrm{n} / \mathrm{kg} \text { sludge }= \\
& \left(10^{(5.69034-2644.11 / 283.16) *} 1000 / 241\right) * 0.09 * \operatorname{Exp}\left[\left({ }^{10(5.69034-2644.11 / 283.16)}\right) * t\right] \\
& =8.408 \mathrm{E}-5 \text { gmoles } \mathrm{UH}_{3} \text { per hour } / \mathrm{kg} \text { sludge }
\end{aligned}
$$

and since $7 / 2$ moles of hydrogen are produced per mole of $\mathrm{UH}_{3}$ reacted:

$=2.942 \mathrm{E}-4$ gmoles $\mathrm{H}_{2}$ per hour $/ \mathrm{kg}$ sludge

This calculation is typical of the calculations found in Table 2-5 and Figure 2-3.

The hydrogen generation can never exceed that available, if all of the hydride in the sample were converted to hydrogen. The total hydride in one $\mathrm{kg}$ of sludge is assumed to be 90 grams. If all of this hydride were converted to hydrogen, the maximum amount is:

$90 / 241^{*}(7 / 2)=1.307$ moles hydrogen $/ \mathrm{kg}$ sludge.

Table 2-5. Hydrogen Generation from Uranium Hydride in Sludge in a Flooded MCO.

\begin{tabular}{||c|c|c|c|c|c||}
\hline \multirow{2}{*}{ Log Hours } & $\mathbf{1 0}$ & $\mathbf{2 0}$ & $\mathbf{5 0}$ & $\mathbf{7 5}$ & 100 \\
\cline { 2 - 6 } & $2.942 \mathrm{E}-04$ & $6.125 \mathrm{E}-04$ & $4.199 \mathrm{E}-03$ & $1.610 \mathrm{E}-02$ & $5.052 \mathrm{E}-02$ \\
\hline 0 & $2.939 \mathrm{E}-03$ & $6.112 \mathrm{E}-03$ & $4.139 \mathrm{E}-02$ & $1.523 \mathrm{E}-01$ & $4.243 \mathrm{E}-01$ \\
\hline 1 & $2.907 \mathrm{E}-02$ & $5.975 \mathrm{E}-02$ & $3.555 \mathrm{E}-01$ & $8.895 \mathrm{E}-01$ & $1.158 \mathrm{E}-00$ \\
\hline 2 & $2.405 \mathrm{E}-01$ & $4.048 \mathrm{E}-01$ & $5.065 \mathrm{E}-01$ & $5.065 \mathrm{E}-1$ & $5.065 \mathrm{E}-1$ \\
\hline 3 & &
\end{tabular}

* Units are in gmoles of hydrogen $/ \mathrm{cm}^{2}$. 
Figure 2-3. Hydrogen Generation From Uranium Hydride in a Flooded MCO.

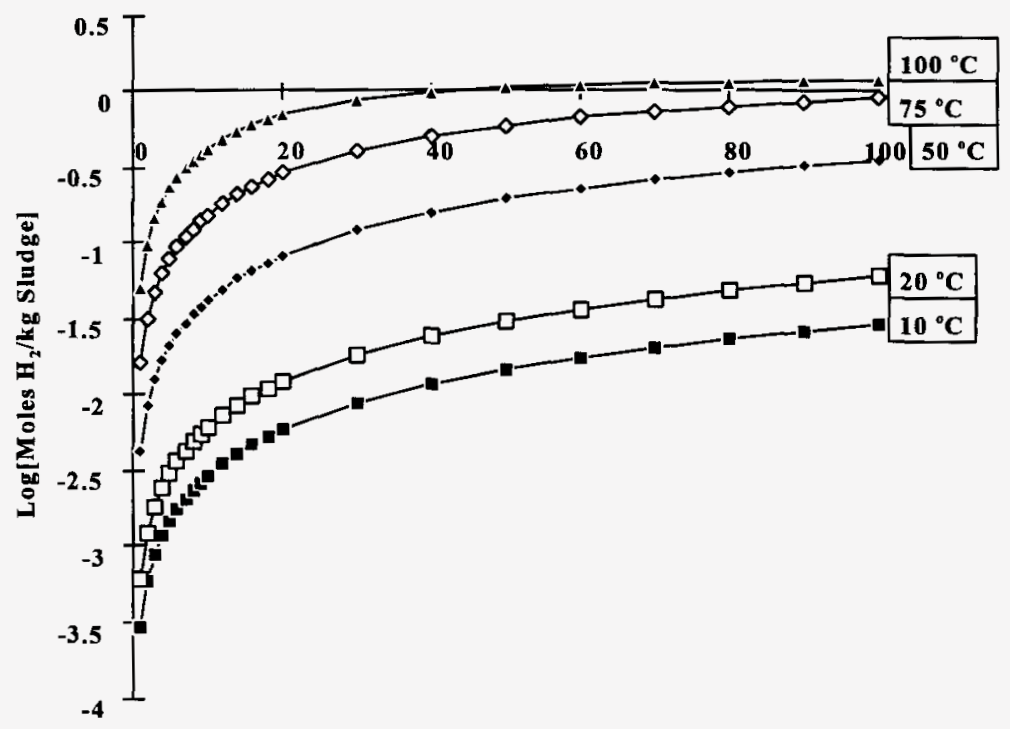

Time Hours

Figure 2-3 shows that sludge can be a significant source of hydrogen. One $\mathrm{kg}$ of sludge at $100^{\circ} \mathrm{C}$ can generate a mole of hydrogen in 40 hours. This is five times the flammability limit in a flooded MCO.

\subsection{FISSION PRODUCT GAS RELEASE IN A FLOODED MCO}

Fission product gases diffuse slowly from the oxide corrosion product. The release rate is too slow to significantly affect the MCO pressure. 


\subsection{HELIUM GAS RELEASE IN A FLOODED MCO}

Helium gas forms from the alpha particles emitted by heavy metals. This helium is not a significant factor in the pressurization of the MCO.

\subsection{WATER VAPOR PRESSURE IN A FLOODED MCO}

The partial pressure of water increases as the temperature of the $\mathrm{MCO}$ is raised. The increase in the number of gmoles of water vapor as the $\mathrm{MCO}$ heats from $10^{\circ} \mathrm{C}$ to any final temperature was added to the other gases to establish the final $\mathrm{MCO}$ pressure.

\subsection{PRESSURIZATION OF A SEALED FLOODED MCO}

Pressurization of a sealed flooded MCO is caused by the accumulation of all of the gases previously discussed. To illustrate the calculation, for the following set of parameters:

- Reactive metal surface area $=127,233 \mathrm{~cm}^{2}$ as described for a "worst-case" $\mathrm{MCO}$ (WHC 1996b)

- $\quad$ Sludge mass $=2.7 \mathrm{~kg}$

- Headspace $=44$ liters

- Temperature $=10^{\circ} \mathrm{C}$

- Radiation energy absorption as described in Tables 2-1 and 2-2

- $\quad$ Time $=1$ hour

The rate of pressurization of a flooded MCO can be modeled in the following manner:

Total gmoles of hydrogen $=$ gmoles of radiolytic hydrogen + gmoles of hydrogen from metal reaction + gmoles of hydrogen from hydride reactions with water

$=((0.002139)+0+(127233 * 6.007 \mathrm{E}-07)+(0.0002942 * 2.7))$

Since hydrogen is soluble in water, Henry's law can be used to estimate the hydrogen fraction remaining in the vapor phase:

$$
\mathrm{M}_{\mathrm{b}}=\mathrm{k}_{\mathrm{m}} \mathrm{P}=\mathrm{k}_{\mathrm{m}}^{*} \mathrm{~N}_{\mathrm{b}} * \mathrm{R} * \mathrm{~T} / \mathrm{V}
$$

Where $\mathrm{M}_{\mathrm{b}}$ is the number of gmoles of hydrogen in the liquid phase

$\mathrm{k}_{\mathrm{m}}$ is henry's constant in gmoles per $1000 \mathrm{~g}$ solvent per atm.

$N_{b}$ is the number of gmoles in the gas phase

$\mathrm{R}$ is the universal gas constant

$\mathrm{T}$ is absolute temperature

$\mathrm{V}$ is the free volume in liters 
$\mathrm{M}_{\mathrm{b}}$ and $\mathrm{N}_{\mathrm{b}}=$ total gmoles of hydrogen

by solving the above 2 equations simultaneously, one may calculate the number of moles of hydrogen remaining in the gas phase.

Pressure increase in atmospheres $=$

(gmoles water vapor) $+($ gmoles of hydrogen in the vapor phase $) * 0.08205 * 283.16 / 44$

$=(0+(0.0644073))^{*}(0.08205 * 283.16 / 44)$

$=0.0340$

The remaining calculations for the $2.7 \mathrm{~kg}$ sludge case, the $16 \mathrm{~kg}$ sludge case, and the $277 \mathrm{~kg}$ sludge case are found in Tables 2-6, 2-7, and 2-8, and Figures 2-4, 2-5, and 2-6. 
Table 2-6. Pressure Increase for a Flooded MCO With $2.7 \mathrm{~kg}$ Sludge.*

\begin{tabular}{||c|c|c|c|c|c||}
\hline \multirow{2}{*}{ Time Hours } & \multicolumn{5}{|c|}{ Temp $\left({ }^{\circ} \mathbf{C}\right)$} \\
\cline { 2 - 6 } & $\mathbf{1 0}$ & $\mathbf{2 0}$ & $\mathbf{5 0}$ & $\mathbf{7 5}$ & $\mathbf{1 0 0}$ \\
\hline 1 & 0.0340 & 0.0885 & 0.7905 & 3.5410 & 12.789 \\
\hline 5 & 0.1700 & 0.4002 & 3.5683 & 16.352 & 60.927 \\
\hline 10 & 0.3401 & 0.7898 & 7.0402 & 32.400 & 121.05 \\
\hline 20 & 0.6807 & 1.5690 & 13.983 & 64.481 & 241.20 \\
\hline 30 & 1.0202 & 2.3481 & 20.923 & 96.550 & 361.20 \\
\hline 40 & 1.3603 & 3.1272 & 27.862 & 128.60 & 481.14 \\
\hline 50 & 1.7003 & 3.9063 & 4.800 & 160.64 & 601.04 \\
\hline 60 & 2.0404 & 4.6853 & 41.737 & 192.66 & 720.92 \\
\hline 70 & 2.3804 & 5.4643 & 48.672 & 224.67 & 840.78 \\
\hline 80 & 2.7204 & 6.2433 & 55.605 & 256.67 & 960.62 \\
\hline 90 & 3.0605 & 7.0222 & 62.538 & 288.67 & 1080.5 \\
\hline 100 & 3.4005 & 7.8011 & 69.470 & 320.65 & 1200.3 \\
\hline
\end{tabular}

* Units are in atmospheres. 
Figure 2-4. Pressurization of Flooded-Sealed "Worst-Case" MCO With 2.7 kg Sludge.

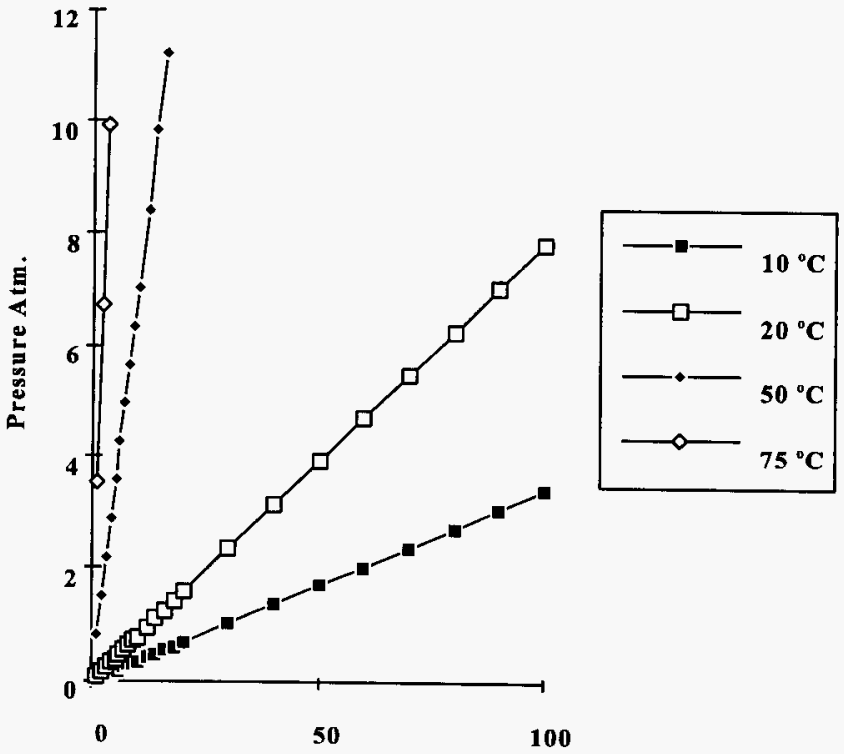

Time Hours

Figure 2-4 shows that for a sealed and flooded MCO containing $2.7 \mathrm{~kg}$ of sludge, the nominal 10 atmosphere limit is reached between 100 and 1000 hours at $10^{\circ} \mathrm{C}$ and $20^{\circ} \mathrm{C}, 15$ hours at $50^{\circ} \mathrm{C}, 3$ hours at $75^{\circ} \mathrm{C}$, and less than 1 hour at $100^{\circ} \mathrm{C}$. 
Table 2-7. Pressure Increase for a Flooded MCO With $16 \mathrm{~kg}$ Sludge.*

\begin{tabular}{|c|c|c|c|c|c|}
\hline \multirow{2}{*}{ Time Hours } & \multicolumn{5}{|c|}{ Temp $\left({ }^{\circ} \mathbf{C}\right)$} \\
\cline { 2 - 6 } & $\mathbf{1 0}$ & $\mathbf{2 0}$ & $\mathbf{5 0}$ & $\mathbf{7 5}$ & $\mathbf{1 0 0}$ \\
\hline 1 & 0.0358 & 0.0921 & 0.8148 & 3.6022 & 13.074 \\
\hline 5 & 0.1789 & 0.4182 & 3.6889 & 16.805 & 62.241 \\
\hline 10 & 0.3577 & 0.8258 & 7.2794 & 33.279 & 123.44 \\
\hline 20 & 0.7154 & 1.6409 & 14.453 & 66.142 & 245.15 \\
\hline 30 & 1.0730 & 2.4556 & 21.615 & 98.936 & 366.04 \\
\hline 40 & 1.4306 & 3.2702 & 28.768 & 131.63 & 486.57 \\
\hline 50 & 1.7881 & 4.0846 & 35.913 & 164.23 & 606.87 \\
\hline 60 & 2.1456 & 4.8988 & 43.050 & 196.75 & 727.01 \\
\hline 70 & 2.5030 & 5.7128 & 50.180 & 229.21 & 847.05 \\
\hline 80 & 2.8604 & 6.5266 & 57.302 & 261.60 & 967.01 \\
\hline 90 & 3.2177 & 7.3402 & 64.417 & 293.93 & 1086.93 \\
\hline 100 & 3.2177 & 8.1536 & 71.525 & 326.22 & 1206.82 \\
\hline \hline
\end{tabular}

* Units are in atmospheres. 
Figure 2-5. Pressurization of Flooded-Sealed "Worst-Case" MCO With $16 \mathrm{~kg}$ Sludge.

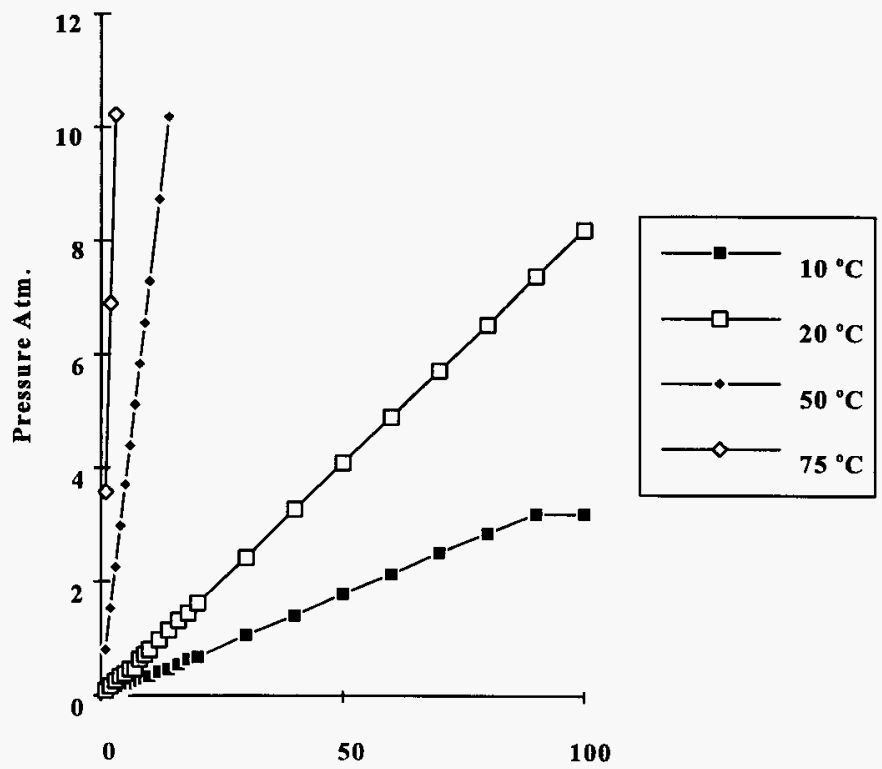

Time Hours

Figure 2-5 shows that for a sealed and flooded MCO containing $16 \mathrm{~kg}$ of sludge, the nominal 10 atmosphere limit is reached between 100 and 1000 hours at $10^{\circ} \mathrm{C}$, approximately 100 hours at $20^{\circ} \mathrm{C}, 14$ hours at $50{ }^{\circ} \mathrm{C}, 3$ hours at $75^{\circ} \mathrm{C}$, and less than 1 hour at $100^{\circ} \mathrm{C}$. 
Table 2-8. Pressure Increase for a Flooded MCO With $277 \mathrm{~kg}$ Sludge.*

\begin{tabular}{|c|c|c|c|c|c|}
\hline \multirow{2}{*}{ Time Hours } & \multicolumn{5}{|c|}{ Temp $\left({ }^{\circ} \mathbf{C}\right)$} \\
\cline { 2 - 6 } & $\mathbf{1 0}$ & $\mathbf{2 0}$ & $\mathbf{5 0}$ & $\mathbf{7 5}$ & $\mathbf{1 0 0}$ \\
\hline 1 & 0.0695 & 0.1621 & 1.2901 & 5.4040 & 18.652 \\
\hline 5 & 0.3462 & 0.7677 & 6.0501 & 25.681 & 88.017 \\
\hline 10 & 0.6947 & 1.5239 & 11.964 & 50.517 & 170.30 \\
\hline 20 & 1.3888 & 3.0337 & 23.667 & 98.712 & 322.71 \\
\hline 30 & 2.0816 & 4.5387 & 35.158 & 145.73 & 460.97 \\
\hline 40 & 2.7737 & 6.0403 & 46.504 & 190.97 & 593.13 \\
\hline 50 & 3.4650 & 7.5386 & 57.709 & 234.66 & 721.20 \\
\hline 60 & 4.1555 & 9.0335 & 68.777 & 276.96 & 846.55 \\
\hline 70 & 4.8454 & 10.525 & 79.714 & 318.05 & 970.06 \\
\hline 80 & 5.5344 & 12.013 & 90.522 & 358.07 & 1092.3 \\
\hline 90 & 6.2226 & 13.498 & 101.20 & 397.14 & 1213.8 \\
\hline 100 & 6.9099 & 14.980 & 111.77 & 435.37 & 1334.8 \\
\hline
\end{tabular}

* Units are in atmospheres. 
Figure 2-6. Pressurization of a Flooded "Worst-Case" MCO With 277 kg Sludge.*

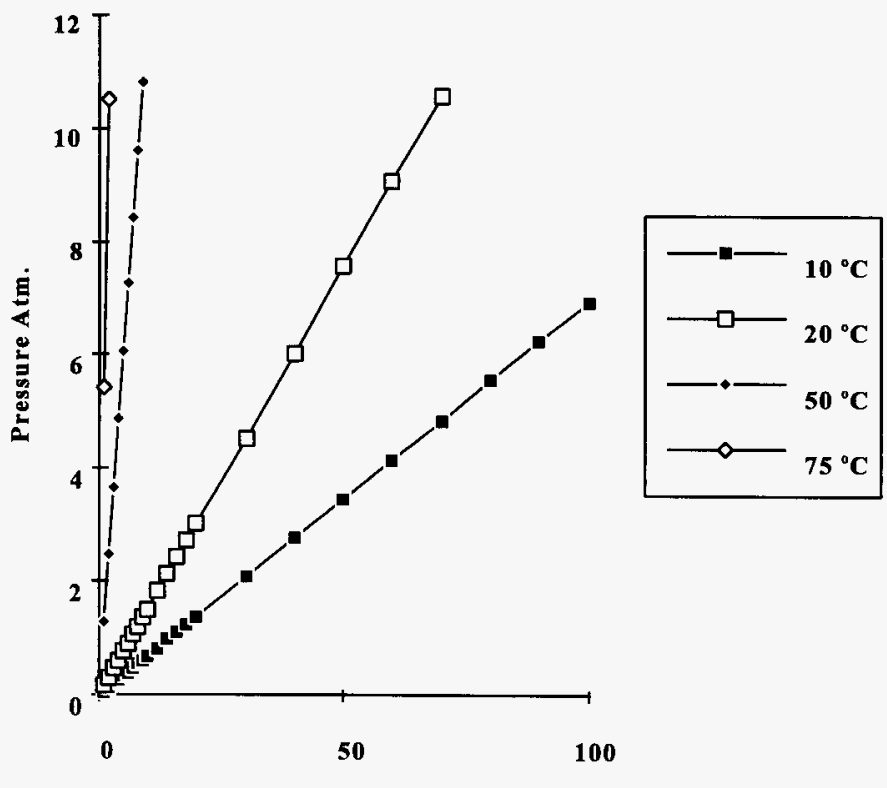

Time Hours

Figure 2-6 shows that for a sealed and flooded MCO containing $277 \mathrm{~kg}$ of sludge, the nominal 10 atmosphere limit is reached between 100 and 1000 hours at $10^{\circ} \mathrm{C}, 70$ hours at $20^{\circ} \mathrm{C}, 9$ hours at $50^{\circ} \mathrm{C}, 2$ hours at $75^{\circ} \mathrm{C}$, and within 30 minutes at $100{ }^{\circ} \mathrm{C}$. 


\subsection{SUMMARY FOR FLOODED CASE}

Uncorroded Fuel - For uncorroded fuel, the gas production is limited to the radiolytically produced gases. Since the $\mathrm{MCO}$ will be vented while in the K Basins area, these radiolytic gases do not pressurize the $\mathrm{MCO}$. They do represent a flammability or detonation hazard unless the $\mathrm{MCO}$ is vented and purged.

During shipping to the CVD station, the MCO may be sealed. If this shipment is limited to 8 hours, the amount of hydrogen and oxygen generated radiolytically are 0.021 and 0.010 moles respectively. At ambient temperatures, this corresponds to 1.1 and 0.55 volume \%, respectively. If a void volume of 44 liters is assumed within the $\mathrm{MCO}$ lid, this increases the static pressure by the ratio of $\mathrm{N} / \mathrm{N}_{0}$,

where:

$$
\begin{aligned}
& N=\text { number of moles of gas after radiolysis event } \\
& N_{o}=\text { number of moles of gas before radiolysis event } \\
& N / N_{o}=1.92 / 1.89=1.016 .
\end{aligned}
$$

This pressure increase is therefore $1.6 \%$ and the hydrogen and oxygen concentrations are below reasonable detonable limits (WHC 1996d).

It has been shown that for non-corroded fuel containing large amounts of sludge, flammable mixtures of hydrogen and oxygen will be reached within two days. Shipping and packaging regulations prevent shipment after one day without a means of a safety class venting and dilution system.

Corroded Fuel - For the worst-case high surface area MCO (in an unsealed, oxygenated MCO environment), oxygen is fixed by the reactive fuel, and hydrogen is limited to that produced radiolytically. The protection of oxygen is a significant concept. As long as oxygen is present, hydrogen is not chemically generated in significant amounts, and the overall corrosion rate that releases heat is 20 times slower than in an oxygen-free environment.

Unless positive measures are introduced to insure the presence of oxygen, it is conservatively assumed the reactions proceed by oxygen-free kinetics with the simultaneous production of hydrogen gas.

Figures 2-4 through 2-6 show that the time to reach the nominal 10 atmosphere limit is exponentially related to temperature and in some positive fashion to the amount of sludge. With large amounts of sludge $(277 \mathrm{~kg})$ and with high temperatures $\left(100^{\circ} \mathrm{C}\right)$, the pressure limit is reached in a flooded, sealed MCO in 26 minutes. 


\subsection{DRAINED CASE}

At the CVD station, the MCO will be heated until the interior temperatures are in the $50-75^{\circ} \mathrm{C}$ range and will then be drained. Upon draining, the free volume of the $\mathrm{MCO}$ is approximately 500 liters. Interior surfaces will be damp, void spaces within the fuel assemblies may still contain liquid water, and a small residual heel of liquid water is expected in the bottom of the MCO. Fourteen $\mathrm{kg}$ of water is a reasonable estimate for the residual water. The drained case possesses unique safety concerns since the corrosion reactivity is the same as for the flooded case, but the ability of the system to conduct heat to the environment is much smaller.

\subsection{UNCORRODED FUEL IN A DRAINED MCO}

From Tables 2-1 and 2-2, the total hydrogen generation rates are derived for the $2.7 \mathrm{~kg}$ sludge case, the $16 \mathrm{~kg}$ sludge case, and the $277 \mathrm{~kg}$ sludge case. From these generation rates, the production of radiolytic gases can be calculated as a function of time. This data for the drained state is presented in Table 3-1 and Figure 3-1.

Table 3-1. Radiolytic Gas Generation for Uncorroded Fuel in a Drained MCO.*

\begin{tabular}{|c|l|l|l|l|l|l||}
\hline \multirow{2}{*}{$\begin{array}{c}\text { Time } \\
\text { Hours }\end{array}$} & \multicolumn{2}{|c|}{ 2.7 kg sludge } & \multicolumn{2}{c|}{ 16 kg sludge } & \multicolumn{2}{c|}{ 277 kg sludge } \\
\cline { 2 - 7 } & Hydrogen & Oxygen & Hydrogen & Oxygen & Hydrogen & \multicolumn{1}{c|}{ Oxygen } \\
\hline 1 & 0.000106 & 0.000053 & 0.000321 & 0.000161 & 0.004479 & 0.002239 \\
\hline 5 & 0.000532 & 0.000266 & 0.003214 & 0.001607 & 0.02239 & 0.01120 \\
\hline 10 & 0.001063 & 0.000532 & 0.006427 & 0.003214 & 0.04479 & 0.02239 \\
\hline 20 & 0.002127 & 0.001063 & 0.009641 & 0.004821 & 0.08958 & 0.04479 \\
\hline 30 & 0.003190 & 0.001595 & 0.012855 & 0.006427 & 0.01343 & 0.06718 \\
\hline 40 & 0.004253 & 0.002127 & 0.016069 & 0.008034 & 0.01792 & 0.08958 \\
\hline 50 & 0.005316 & 0.002658 & 0.019282 & 0.009641 & 0.22394 & 0.11197 \\
\hline 60 & 0.006380 & 0.003190 & 0.020568 & 0.010284 & 0.26873 & 0.13436 \\
\hline 70 & 0.007434 & 0.003717 & 0.022304 & 0.011252 & 0.31351 & 0.15676 \\
\hline
\end{tabular}

* Units are moles of gases. 
Figure 3-1. Radiolytic Gas Generation for Uncorroded Fuel in a Drained MCO.

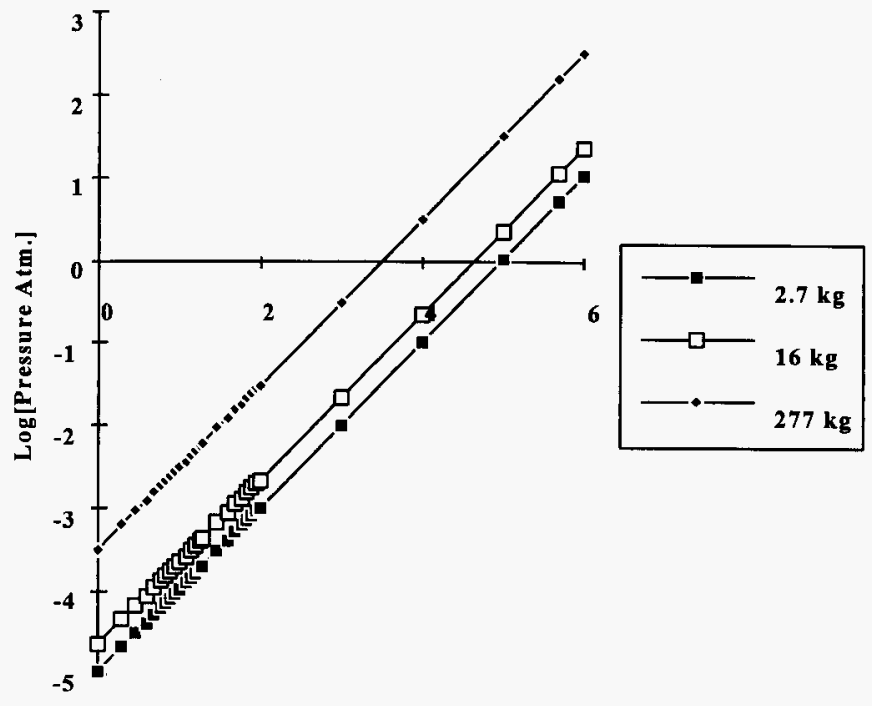

\section{Log [Time Hrs.]}

These amounts of hydrogen and oxygen are trivial and are not expected to influence the pressure or flammability of the MCO. 


\subsection{CORRODED FUEL IN A DRAINED MCO}

The gas generation rate for corroded fuel must include both radiolysis gases and chemically generated gases. The chemically generated gases are discussed next.

\subsubsection{Hydrogen Generated by Water Reaction on Uranium Metal in a Drained MCO}

By draining the $\mathrm{MCO}$ and replacing the atmosphere with inert gas, the residual oxygen in the $\mathrm{MCO}$ is reduced to a very small concentration and ceases to moderate the chemical reactivity of the uranium with water. Since the atmosphere is saturated with water vapor, the exposed uranium will react at its maximum deoxygenated rate. The deoxygenated reaction rate constant for uranium with liquid water is the same as for uranium with $100 \% \mathrm{RH}$ vapor. Therefore, the same chemical hydrogen generation rates for the drained state are expected for the deoxygenated flooded case. (Refer to Table 2-4 and Figure 2-2 for the hydrogen generation rate per $\mathrm{cm}^{2}$ of reactive uranium metal.)

\subsubsection{Hydrogen Generated by Water Reaction on Uranium Hydride in a Drained MCO}

Since the water vapor remains at $100 \% \mathrm{RH}$, the reaction rate for uranium hydride should remain the same as for the flooded $\mathrm{MCO}$ case. The hydrogen generation rates from the reaction of water vapor with uranium hydride can be seen in Table 2-5 and Figure 2-3.

\subsubsection{Fission Product Gas Release in a Drained MCO}

Fission product gases diffuse slowly from the oxide corrosion product. The release rate is too slow to significantly affect the MCO pressure.

\subsubsection{Helium Gas Release in a Drained MCO}

Helium gas forms from the alpha particles emitted by heavy metals. This helium is not a significant factor in the pressurization of the MCO.

\subsubsection{Water Vapor Pressure in a Drained MCO}

The partial pressure of water increases as the temperature of the $\mathrm{MCO}$ is raised. The increase in the number of gmoles of water vapor, as the $\mathrm{MCO}$ heats from $10^{\circ} \mathrm{C}$ to any final temperature, was added to the other gases to establish the final MCO pressure. 


\subsubsection{Pressurization of a Sealed Drained MCO}

Pressure in a sealed, drained MCO will be less than for a flooded $\mathrm{MCO}$, at a given temperature, for several reasons. The free volume has increased from 44 liters to 500 , and the radiolytic gas generation rate is smaller. As an example, assuming the following parameters:

- Reactive metal surface area $=127233 \mathrm{~cm}^{2}$ as described for a "worst-case" MCO. (WHC 1996b)

- $\quad$ Sludge mass $=2.7 \mathrm{~kg}$

- Headspace $=500$ liters

- Temperature $=10^{\circ} \mathrm{C}$

- Radiation energy absorption as described in Tables 2-1 and 2-2

- $\quad$ Time $=1$ hour

The rate of pressurization of a drained $\mathrm{MCO}$ can be modeled by summing in the following manner:

Pressure increase in atmospheres $=$

(gmoles radiolysis gases) + (gmoles water vapor) +

(reactive metal surface area * (gmoles $\mathrm{H}_{2}$ metal $/ \mathrm{cm}^{2}+$ gmoles $\left.\mathrm{H}_{2 \mathrm{UH}-3} / \mathrm{cm}^{2}\right)$ ) * $0.08205 * 283.16 / 44$

$=(0.0000000893 * 3600 * 1)+(0)+(127233 *(6.007 \mathrm{E}-07+1.6625 \mathrm{E}-08))$

$* 0.08205 * 283.16 / 44$

$=0.041728 \mathrm{~atm}$.

The remaining calculations are found in Tables 3-2, 3-3, 3-4 and Figures 3-2, 3-3, 3-4. 
Table 3-2: Pressure Increase for a Drained MCO With $2.7 \mathrm{~kg}$ Sludge.*

\begin{tabular}{||c|c|c|c|c|c||}
\hline \multirow{2}{*}{ Time Hours } & \multicolumn{5}{|c|}{ Temp ( $\left.{ }^{\circ} \mathbf{C}\right)$} \\
\cline { 2 - 6 } & $\mathbf{1 0}$ & $\mathbf{2 0}$ & $\mathbf{5 0}$ & $\mathbf{7 5}$ & $\mathbf{1 0 0}$ \\
\hline 1 & 0.0036 & 0.0092 & 0.0829 & 0.3743 & 1.3884 \\
\hline 5 & 0.0180 & 0.0423 & 0.3807 & 1.7658 & 6.6759 \\
\hline 10 & 0.0359 & 0.0837 & 0.7529 & 3.5046 & 13.280 \\
\hline 20 & 0.0719 & 0.1665 & 1.4972 & 6.9807 & 26.477 \\
\hline 30 & 0.1078 & 0.2493 & 2.2413 & 10.456 & 39.658 \\
\hline 40 & 0.1437 & 0.3321 & 2.9852 & 13.929 & 52.832 \\
\hline 50 & 0.1797 & 0.4149 & 3.7290 & 17.400 & 66.002 \\
\hline 60 & 0.2156 & 0.4977 & 4.4727 & 20.870 & 79.169 \\
\hline 70 & 0.2515 & 0.5804 & 5.2161 & 24.338 & 92.334 \\
\hline 80 & 0.2874 & 0.6632 & 5.9595 & 27.806 & 105.49 \\
\hline 90 & 0.3233 & 0.7460 & 6.7028 & 31.272 & 118.66 \\
\hline 100 & 0.3593 & 0.8287 & 7.4459 & 34.738 & 131.82 \\
\hline & & & & & \\
\hline
\end{tabular}

* Units are in atmospheres pressure. 
Figure 3-2. Pressurization of a Drained-Sealed "Worst-Case" MCO $2.7 \mathrm{~kg}$ Sludge.

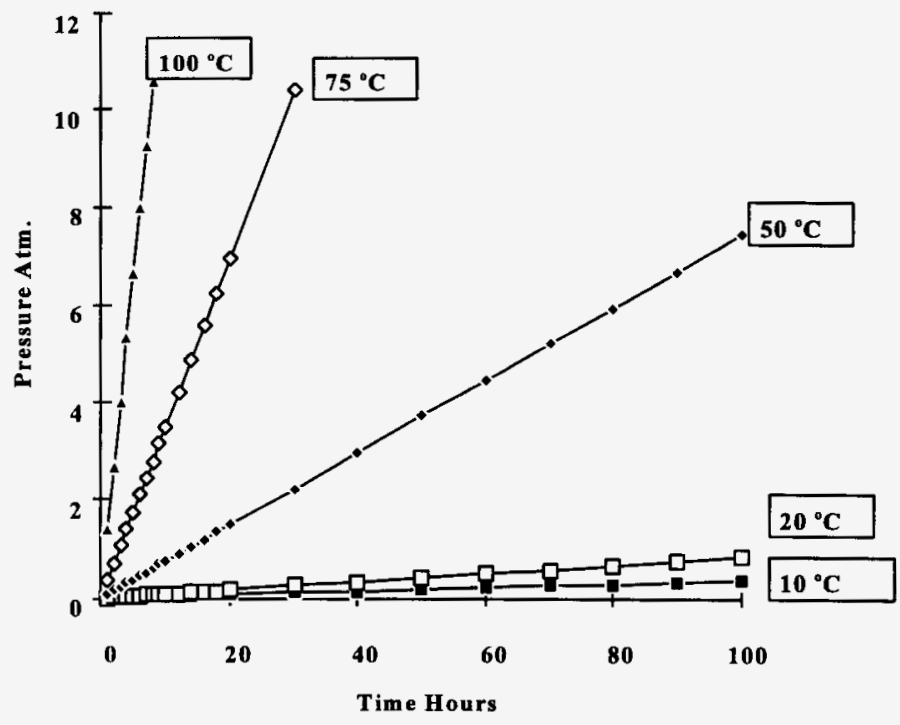

Figure $3-2$ shows that for a sealed and flooded MCO containing $2.7 \mathrm{~kg}$ of sludge, the nominal 10 atmosphere limit is reached in 2794 hours at $10^{\circ} \mathrm{C}, 1087$ hours at $20^{\circ} \mathrm{C}$, 134.4 hours at $50{ }^{\circ} \mathrm{C}, 28.7$ hours at $75^{\circ} \mathrm{C}$, and within 7.5 hours at $100^{\circ} \mathrm{C}$. 
Table 3-3. Pressure Increase for a Drained MCO With $16 \mathrm{~kg}$ Sludge.*

\begin{tabular}{|c|c|c|c|c|c|}
\hline \multirow[b]{2}{*}{ Time Hours } & \multicolumn{5}{|c|}{ Temp $\left({ }^{\circ} \mathrm{C}\right)$} \\
\hline & 10 & 20 & 50 & 75 & 100 \\
\hline 1 & 0.0038 & 0.0096 & 0.0855 & 0.3842 & 1.4197 \\
\hline 5 & 0.0189 & 0.0443 & 0.3937 & 1.8148 & 6.8202 \\
\hline 10 & 0.0378 & 0.0876 & 0.7786 & 3.6000 & 13.543 \\
\hline 20 & 0.0757 & 0.1743 & 1.5477 & 7.1607 & 26.911 \\
\hline 30 & 0.1135 & 0.2609 & 2.3156 & 10.714 & 40.189 \\
\hline 40 & 0.1514 & 0.3475 & 3.0825 & 14.257 & 53.429 \\
\hline 50 & 0.1892 & 0.4341 & 3.8485 & 17.789 & 66.642 \\
\hline 60 & 0.2270 & 0.5206 & 4.6137 & 21.313 & 79.839 \\
\hline 70 & 0.2648 & 0.6072 & 5.3781 & 24.829 & 93.024 \\
\hline 80 & 0.3026 & 0.6937 & 6.1417 & 28.339 & 106.20 \\
\hline 90 & 0.3404 & 0.7802 & 6.9045 & 31.843 & 119.37 \\
\hline 100 & 0.3782 & 0.8667 & 7.6666 & 35.341 & 132.54 \\
\hline
\end{tabular}

* Units are in atmospheres pressure. 
Figure 3-3. Pressurization of a Drained-Sealed "Worst-Case" MCO $16 \mathrm{~kg}$ Sludge."

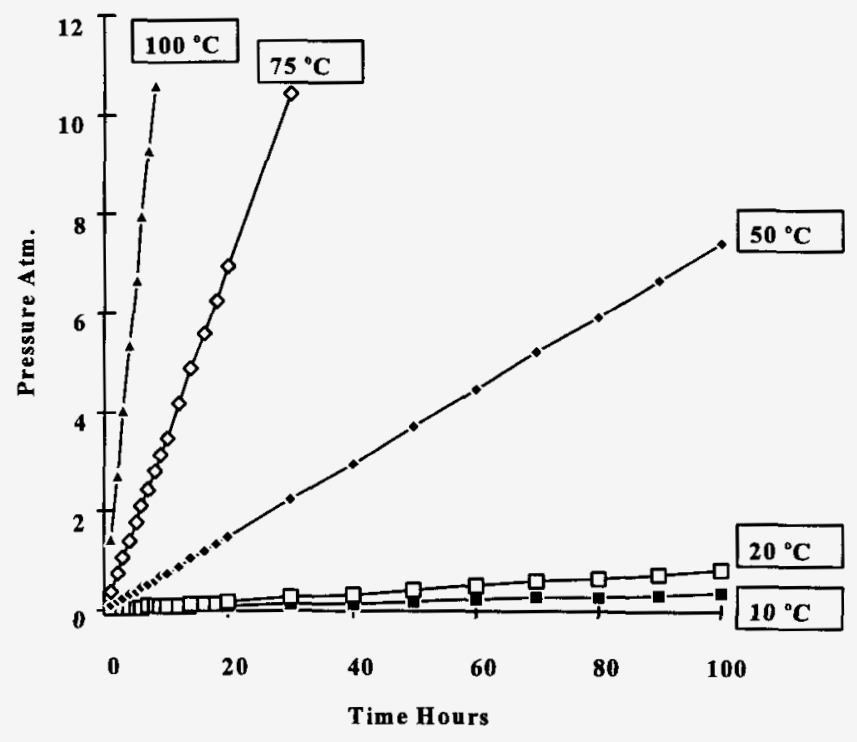

Figure 3-3 shows that for a sealed and flooded MCO containing $16 \mathrm{~kg}$ of sludge, the nominal 10 atmosphere limit is reached in 2698 hours at $10^{\circ} \mathrm{C}, 1175$ hours at $20^{\circ} \mathrm{C}$, 130.7 hours at $50{ }^{\circ} \mathrm{C}$, in 28 hours at $75^{\circ} \mathrm{C}$, and within 7.4 hours at $100^{\circ} \mathrm{C}$. 
Table 3-4. Pressure Increase for a Drained MCO With $277 \mathrm{~kg}$ Sludge.*

\begin{tabular}{|c|c|c|c|c|c||}
\hline \multirow{2}{*}{ Time Hours } & \multicolumn{5}{|c|}{ Temp $\left({ }^{\circ} \mathbf{C}\right)$} \\
\cline { 2 - 6 } & $\mathbf{1 0}$ & $\mathbf{2 0}$ & $\mathbf{5 0}$ & $\mathbf{7 5}$ & $\mathbf{1 0 0}$ \\
\hline 1 & 0.0075 & 0.0172 & 0.1366 & 0.5796 & 2.0325 \\
\hline 5 & 0.0377 & 0.0823 & 0.6476 & 2.7774 & 9.6521 \\
\hline 10 & 0.0754 & 0.1637 & 1.2825 & 5.4692 & 18.691 \\
\hline 20 & 0.1508 & 0.3260 & 2.5388 & 10.693 & 35.433 \\
\hline 30 & 0.2260 & 0.4878 & 2.7725 & 15.789 & 50.621 \\
\hline 40 & 0.3011 & 0.6493 & 4.9904 & 20.693 & 65.138 \\
\hline 50 & 0.3761 & 0.8104 & 6.1933 & 25.427 & 79.206 \\
\hline 60 & 0.4511 & 0.9712 & 7.3815 & 30.013 & 92.975 \\
\hline 70 & 0.5260 & 1.1315 & 8.5556 & 34.466 & 106.54 \\
\hline 80 & 0.6008 & 1.2916 & 9.7159 & 38.804 & 119.98 \\
\hline 90 & 0.6755 & 1.5413 & 10.863 & 43.038 & 133.32 \\
\hline 100 & 0.7501 & 1.6106 & 11.997 & 47.182 & 146.61 \\
\hline
\end{tabular}

* Units are in atmospheres pressure. 
Figure 3-4. Pressurization of a Drained-Sealed "Worst Cast" MCO 277 kg Sludge.*

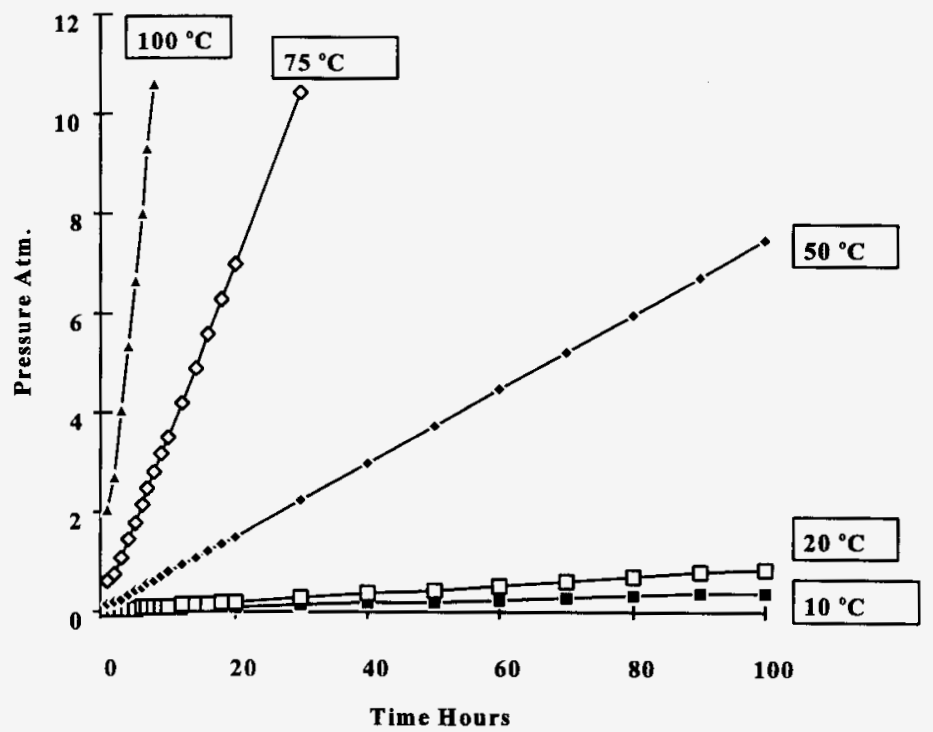

Figure 3-4 shows that for a sealed and flooded $\mathrm{MCO}$ containing $277 \mathrm{~kg}$ of sludge, the nominal 10 atmosphere limit is reached in 1486 hours at $10^{\circ} \mathrm{C}, 695$ hours at $20^{\circ} \mathrm{C}, 82.5$ hours at $50{ }^{\circ} \mathrm{C}, 18.7$ hours at $75{ }^{\circ} \mathrm{C}$, and within 5.2 hours at $100^{\circ} \mathrm{C}$. 


\subsection{COLD VACUUM DRYING}

The CVD process is designed to remove the bulk of the water from the $\mathrm{MCO}$, prior to shipping and storage in the CSB. The drained $\mathrm{MCO}$ will be evacuated by roughing vacuum pumps.

As the pressure drops, the free water begins to boil when the system pressure reaches the partial pressure of water at the MCO temperature. The free water rapidly cools as it boils until finally, an equilibrium temperature is achieved based upon the heat flow into the sample and the water vapor removal rate of the vacuum system. This process also establishes an equilibrium system pressure.

\subsection{RADIOLYTIC GAS PRODUCTION FOR UNCORRODED FUEL DURING CVD}

At the beginning of the CVD process, the radiolytic gas generation rate will not be different from the drained MCO case previously considered. By the end of the CVD process, the radiolytic rate will have slowed due to the removal of the free water. These radiolytic rates are trivial and do not significantly affect the MCO during the CVD operation.

\subsection{GAS GENERATION FROM CORRODED FUEL DURING CVD}

The radiolytic gas production does not vary significantly for corroded fuel from the uncorroded case. The discussion from Section 4.1 can therefore be applied to corroded fuel.

\subsubsection{Hydrogen Generation from Water Reaction with Uranium Metal During CVD}

To calculate the hydrogen generation rate, it is necessary to know the water vapor pressure. An MCO preheated to $75^{\circ} \mathrm{C}$, possesses a water vapor partial pressure of 283.1 torr or $38.42 \mathrm{kPa}$. As the water boils under vacuum, the liquid water temperature rapidly cools until the rate at which heat is supplied to the system equals the rate at which heat is removed by the boiling process. It has been estimated that equilibrium will be achieved at approximately 90 torr or $11.96 \mathrm{kPa}$. This corresponds to an internal temperature of $50^{\circ} \mathrm{C}$.

It is expected that the water vapor partial pressure would be maintained at approximately 90 torr until the free water is almost exhausted. The pressure would then drop precipitously to the lowest pressure ( 5 torr) maintained by the vacuum pump. 
Equation 4 (Ritchie 1981) allows one to calculate the uranium corrosion rate under deoxygenated conditions for liquid water or a $100 \% \mathrm{RH}$ oxygen-free atmosphere. R. J. Pearce gives an equation (Pearce 1989):

$$
\log K=4.33-2144 / T+0.5 \log [P]
$$

giving the reaction rate constant as a function of both temperature and water partial pressure in $\mathrm{kPa}$. The oxygen fixation rate during CVD is then:

$$
\begin{aligned}
& \text { wt gain in moles } \mathrm{O}_{2} / \mathrm{hr} / \mathrm{cm}^{2}=10^{*} \mathrm{~K} / 32000 \mathrm{mg} / \mathrm{gmole} \\
& =\left(10^{*} 10^{(4.33 \cdot 2144 / \mathrm{T}+0.5 \mathrm{Log}[\mathrm{PI})}\right) / 32000
\end{aligned}
$$

The hydrogen generation rate from uranium metal is then twice that predicted from Equation 18.

During CVD, there is typically more interest in the hydrogen generation rate than the total MCO pressure, since the MCO will not normally pressurize. If, however, some off-normal event plugs the lines, it is possible for the system to pressurize. Therefore, the data are presented in the same format as for the rest of this document. The number of gmoles $/ \mathrm{cm}^{2}$ of hydrogen for the first hour give the initial generation rate.

Table 4-1 and Figure 4-1, give the hydrogen generation rates for corroded fuel during CVD.

\subsubsection{Hydrogen Generation from Water Reaction with Uranium Hydride During CVD}

The equation derived previously for the reaction rate of water with uranium hydride applies to liquid water and to water vapor at $100 \% \mathrm{RH}$.

The water partial pressure is not expected to decrease below $100 \%$ RH during CVD, until the very end of the process step. For this reason, the same equation will be used to predict hydrogen generation rates from uranium hydride as was used previously. The results of these calculations are the same as found for the flooded $\mathrm{MCO}$ and can be found in Table 2-5 and Figure 2-3.

\subsubsection{Fission Product Gas Release During CVD}

Fission product gases diffuse slowly from the oxide corrosion product. The release rate is too slow to significantly affect the MCO pressure. 
Table 4-1. Hydrogen Generation from Water Reaction with Uranium Metal During CVD.*

\begin{tabular}{||c|c|c|c|c|c||}
\hline \multirow{2}{*}{ Time Hours } & \multicolumn{5}{|c|}{ Temp ( $\left.{ }^{\circ} \mathbf{C}\right)$} \\
\cline { 2 - 7 } & $\mathbf{1 0}$ & $\mathbf{2 0}$ & $\mathbf{5 0}$ & $\mathbf{7 5}$ & $\mathbf{1 0 0}$ \\
\hline 1 & $3.96 \mathrm{E}-07$ & $9.91 \mathrm{E}-07$ & $1.09 \mathrm{E}-05$ & $5.76 \mathrm{E}-05$ & $2.41 \mathrm{E}-04$ \\
\hline 5 & $1.98 \mathrm{E}-06$ & $4.96 \mathrm{E}-06$ & $5.44 \mathrm{E}-05$ & $2.87 \mathrm{E}-04$ & $1.20 \mathrm{E}-03$ \\
\hline 10 & $3.96 \mathrm{E}-06$ & $9.91 \mathrm{E}-06$ & $1.09 \mathrm{E}-04$ & $5.76 \mathrm{E}-04$ & $2.41 \mathrm{E}-03$ \\
\hline 20 & $7.93 \mathrm{E}-06$ & $1.98 \mathrm{E}-05$ & $2.17 \mathrm{E}-04$ & $1.15 \mathrm{E}-03$ & $4.83 \mathrm{E}-03$ \\
\hline 30 & $1.19 \mathrm{E}-05$ & $2.97 \mathrm{E}-05$ & $3.26 \mathrm{E}-04$ & $1.73 \mathrm{E}-03$ & $7.24 \mathrm{E}-03$ \\
\hline 40 & $1.59 \mathrm{E}-05$ & $3.96 \mathrm{E}-05$ & $4.35 \mathrm{E}-04$ & $2.30 \mathrm{E}-03$ & $9.65 \mathrm{E}-03$ \\
\hline 50 & $1.98 \mathrm{E}-05$ & $4.96 \mathrm{E}-05$ & $5.43 \mathrm{E}-04$ & $2.88 \mathrm{E}-03$ & $1.21 \mathrm{E}-02$ \\
\hline 60 & $2.38 \mathrm{E}-05$ & $5.95 \mathrm{E}-05$ & $6.52 \mathrm{E}-04$ & $3.45 \mathrm{E}-03$ & $1.45 \mathrm{E}-02$ \\
\hline 70 & $2.77 \mathrm{E}-05$ & $6.94 \mathrm{E}-05$ & $7.61 \mathrm{E}-04$ & $4.03 \mathrm{E}-03$ & $1.69 \mathrm{E}-02$ \\
\hline 80 & $3.17 \mathrm{E}-05$ & $7.93 \mathrm{E}-05$ & $8.69 \mathrm{E}-04$ & $4.60 \mathrm{E}-03$ & $1.93 \mathrm{E}-02$ \\
\hline 90 & $3.57 \mathrm{E}-05$ & $8.92 \mathrm{E}-05$ & $9.78 \mathrm{E}-04$ & $5.18 \mathrm{E}-03$ & $2.17 \mathrm{E}-02$ \\
\hline 100 & $3.96 \mathrm{E}-05$ & $9.91 \mathrm{E}-05$ & $1.09 \mathrm{E}-03$ & $5.76 \mathrm{E}-03$ & $2.41 \mathrm{E}-02$ \\
\hline & & & & & \\
\hline
\end{tabular}

* Units are in atmospheres pressure. 
Figure 4-1. Hydrogen From Water Reaction with Uranium Metal in MCO during CVD.

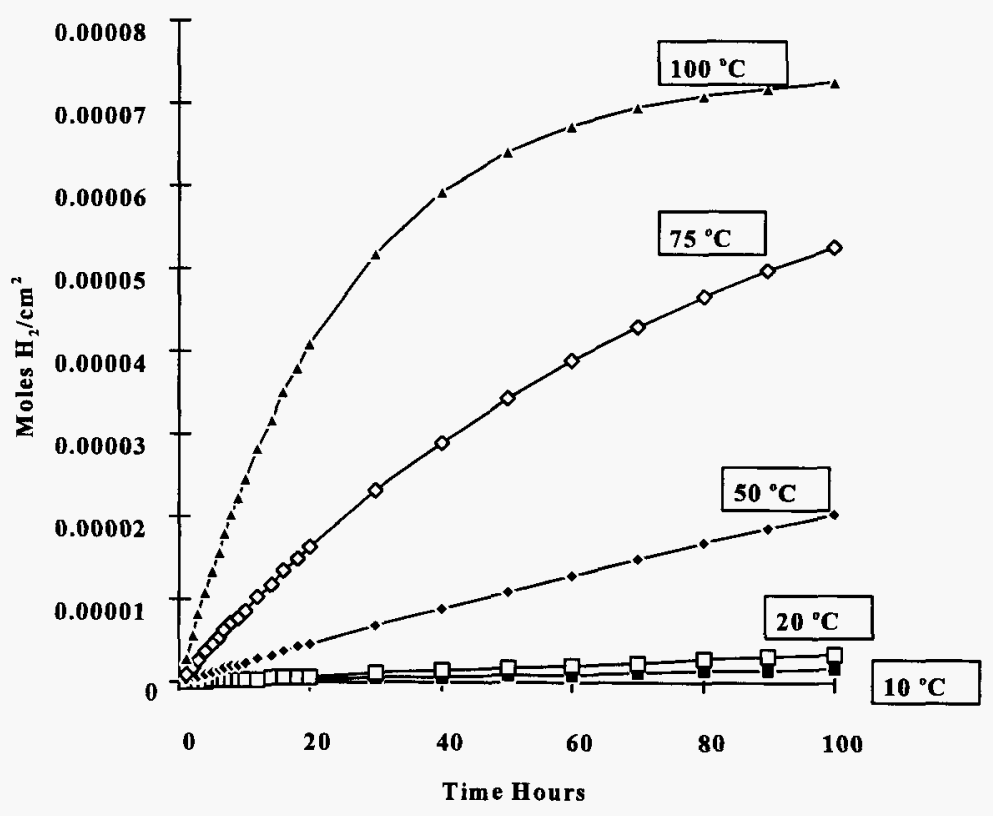

\subsubsection{Helium Gas Release During CVD}

Helium gas forms from the alpha particles emitted by heavy metals. This helium is not a significant factor in the pressurization of the MCO.

\subsubsection{Water Vapor Pressure Increase During CVD}

The partial pressure of water increases as the temperature of the $\mathrm{MCO}$ is raised. The increase in the number of gmoles of water vapor as the $\mathrm{MCO}$ heats from $10{ }^{\circ} \mathrm{C}$ to any final temperature was added to the other gases to establish the final MCO pressure. 


\subsubsection{Pressurization of a Sealed MCO During CVD}

During normal operations, the MCO should not be sealed during CVD, but for those offnormal events where sealing could occur, the pressures will be the same as for the drained $\mathrm{MCO}$ case. 
WHC-SD-SNF-TI-028

Revision 0

This page intentionally left blank. 


\subsection{SHIPPING AND STAGING}

\subsection{RADIOLYTIC GAS PRODUCTION}

After completion of CVD, all free water is postulated to be gone and the residual water within oxides is postulated to not exceed $10 \%$ by volume, or approximately $2-3$ weight $\%$.

Under these conditions, the radiolytic hydrogen generation rate for the $2.7 \mathrm{~kg}$ case is 1.366E-09 moles per second from Table $2-2$ and for the $16 \mathrm{~kg}$ case is $9.687 \mathrm{E}-09$ moles per second

The total hydrogen and oxygen accumulating as a function of time are shown in Table 5-1 and Figure 5-1. These radiolytic gas generation rates are only consequential during long-term storage and are not consequential during shipping and staging.

After two years staging time, and in the absence of appropriate getters, radiolytic hydrogen and oxygen will accumulate in the following amounts:

- For $2.7 \mathrm{~kg}$ of sludge, $\mathrm{H}_{2}=0.1$ and $\mathrm{O}_{2}=0.05$ moles

- For $16 \mathrm{~kg}$ of sludge, $\mathrm{H}_{2}=0.6$ and $\mathrm{O}_{2}=0.3$ moles

- For $277 \mathrm{~kg}$ of sludge $\mathrm{H}_{2}=6.8$ and $\mathrm{O}_{2}=3.4$ moles.

Only 0.9 moles of $\mathrm{O}_{2}$ are required to reach the $5 \%$ flammability limit.

Table 5-1. Radiolytic Gas Generation During Shipping and Staging.

\begin{tabular}{|c|c|c|c|c|c|c|}
\hline \multirow{2}{*}{$\begin{array}{c}\text { Time } \\
\text { Hours }\end{array}$} & \multicolumn{2}{|c|}{ 2.7 kg Sludge } & \multicolumn{2}{c|}{ 16 kg Sludge } & \multicolumn{2}{c|}{ 277 kg Sludge } \\
\cline { 2 - 7 } & Oxygen & Hydrogen & Oxygen & Hydrogen & Oxygen & Hydrogen \\
\hline 0 & $2.94 \mathrm{E}-06$ & $5.89 \mathrm{E}-06$ & $1.74 \mathrm{E}-05$ & $3.488 \mathrm{E}-05$ & 0.0001942 & 0.0003884 \\
\hline 1 & $2.943 \mathrm{E}-5$ & $5.886 \mathrm{E}-5$ & 0.000174 & 0.0003488 & 0.0019422 & 0.0038844 \\
\hline 2 & 0.000294 & 0.000589 & 0.001743 & 0.003488 & 0.019422 & 0.038844 \\
\hline 3 & 0.002943 & 0.005886 & 0.01744 & 0.03488 & 0.19422 & 0.38844 \\
\hline 4 & 0.02943 & 0.05886 & 0.1744 & 0.3488 & 1.9422 & 3.8844 \\
\hline 5 & 0.2943 & 0.5886 & 1.744 & 3.488 & 19.422 & 38.844 \\
\hline 6 & 2.943 & 5.886 & 17.44 & 34.88 & 194.22 & 388.44 \\
\hline
\end{tabular}


Figure 5-1. Radiolytic Gas Generation During Shipping and Staging.

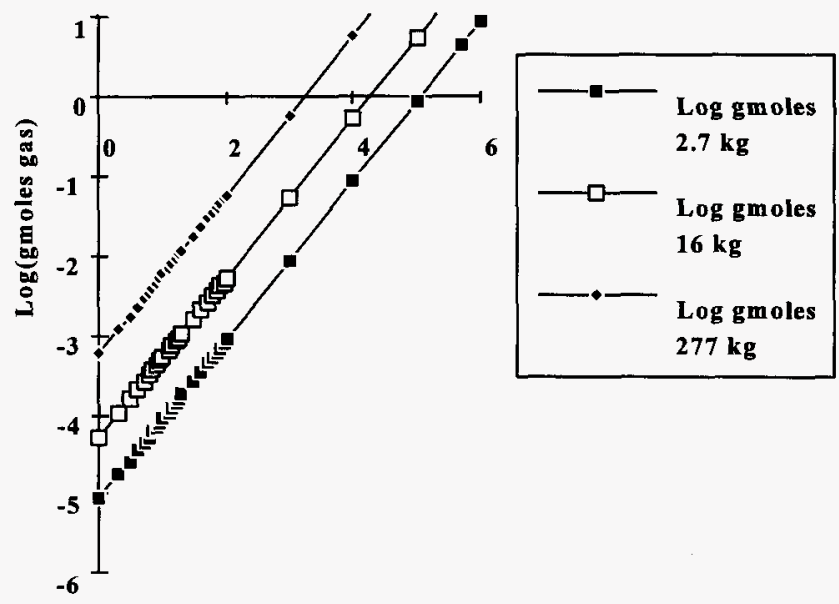

Log(Time Hrs)

\subsection{CHEMICAL GAS GENERATION DURING SHIPPING AND STAGING}

\subsubsection{Estimate of Water Partial Pressure During Shipping}

For the worst-case MCOs with high surface area, the chemical gas generation rate will depend upon the water vapor partial pressure and the temperature. Potential water sources are free water remaining through incomplete CVD, physically absorbed water on surfaces, free water contained in crystal defects within the oxide lattice, chemically bound water as in hydrates, and chemically bound hydroxide ions both on the surface and within the oxide lattice.

If all free water is removed, as should be the case during CVD, the water vapor partial pressure will be determined by the remaining species. 
The types and species of hydrates within the MCO are then considered. These are determined by the types of oxides found in the $\mathrm{MCO}$, and the activities of both oxygen and water in equilibrium with these oxides. Three oxides are found in relatively large abundance in the K-East pool: iron oxide, aluminum oxide, and uranium oxide. The origins of these oxides are as follows:

Structural iron reacts with water as in:

$$
\mathrm{Fe}+2 \mathrm{H}_{2} \mathrm{O} \rightarrow \mathrm{Fe}^{+2}+\mathrm{H}_{2}+2 \mathrm{OH}^{-} \quad \mathrm{pK}_{\mathrm{s}}^{\mathrm{o}}=13.7
$$

The relatively soluble ferrous ions are eventually oxidized to ferric ions by dissolved oxygen:

$$
4 \mathrm{Fe}^{+2}+2 \mathrm{H}_{2} \mathrm{O}+\mathrm{O} 2 \rightarrow 4 \mathrm{Fe}^{+3}+4 \mathrm{OH}^{-} \quad \mathrm{pK}_{\mathrm{s}}{ }^{0}=35.82
$$

Ferric hydroxide settles out of solution as an insoluble precipitate covering all objects including fuel assemblies. Ferric hydroxide typically forms a trihydrate $\left(\mathrm{Fe}_{2} \mathrm{O}_{3} \cdot 3 \mathrm{H}_{2} \mathrm{O}\right)$ at ambient temperature.

Aluminum metal exists in the pool as aluminum cladding upon a few single pass fuel assemblies, and many of the canisters containing fuel assemblies were made of aluminum. This aluminum corrodes in water to form a tightly adherent aluminum oxide $\mathrm{Al}_{2} \mathrm{O}_{3} \cdot 3 \mathrm{H}_{2} \mathrm{O}$ at ambient temperature. Over time, this aluminum oxide can flake off and be carried by water currents to every available surface within the K-East Pool.

Uranium metal corrodes in water to form $\mathrm{UO}_{2}$ :

$$
\mathrm{U}+\mathrm{H}_{2} \mathrm{O}=\mathrm{UO}_{2}+2 \mathrm{H}_{2}
$$

Uranium dioxide does not form hydrates; however, a higher oxide $\mathrm{UO}_{3}$ does. The chemistry of forming the higher oxide is then considered to see if this higher oxide contributes significant amounts of hydrated water to the MCO.

Uranium in $\mathrm{UO}_{2}$ carries a formal charge of +4 . Uranium can also lose two more electrons and go to the +5 and +6 formal oxidation states, as in $\mathrm{UO}_{2}{ }^{+}$and $\mathrm{UO}_{2}{ }^{+}$. These higher oxidation states can form oxides as in $\left(\mathrm{UO}_{2}\right)_{2} \mathrm{O}$ or $\mathrm{U}_{2} \mathrm{O}_{5}$ (not identified as a pure substance) and $\left(\mathrm{UO}_{2}\right) \mathrm{O}$ or $\mathrm{UO}_{3}$. These oxides can be found in a continuum of abundances depending upon the oxygen potential; however, only four pure crystalline phases have been reported: $\mathrm{UO}_{2}, \mathrm{U}_{4} \mathrm{O}_{9}, \mathrm{U}_{3} \mathrm{O}_{8}$, and $\mathrm{UO}_{3}$. Of all of these oxides, only $\mathrm{UO}_{3}$ has been reported to form a hydrate $\left(\mathrm{UO}_{3} \cdot 2 \mathrm{H}_{2} \mathrm{O}\right)$ at ambient temperature.

The next and most important question is, which of these oxides and in what abundance will it be incorporated into the MCO? 
Because only uranium oxides adhere to the uranium metal, it is believed that essentially all of the contaminant aluminum and iron oxides will be removed.

Reasons for this assumption are:

- Exterior coatings of iron and alumimum oxides on the fuel assemblies should be removed by the handling and cleaning processes.

- Both iron and aluminum oxides should be removed from any cavities with large openings by the handling and cleaning processes.

- Aluminum oxides and ferric oxides should not be found behind pinholes and narrow cracks in the cladding. Aluminum oxides are moved as micron-sized particles by water currents from their place of origin, to deposition on or in the fuel assemblies. Narrow cracks or pinholes restrict the size and velocity of water currents carrying aluminum oxide particles. Secondly, the space behind pinholes or narrow cracks are filled with uranium oxides and contain little void space for foreign particles.

Ferrous iron could diffuse through pinholes or narrow cracks, but is not expected to precipitate beneath the cladding due to the reducing environment established by the uranium metal and the slow diffusion of oxygen through the narrow cladding openings.

The $\mathrm{MCO}$ is therefore expected to contain principally uranium metal and uranium oxides. It is known that only $\mathrm{UO}_{2}$ is formed upon reaction of uranium metal with water. Oxygen is required to form the higher oxides. When very small amounts of oxygen are present, $\mathrm{UO}_{2+\mathrm{x}}$ is formed where $x$ typically varies from 0.01 to 0.1 . In water that is in direct contact with the atmosphere, $\mathrm{x}$ usually varies from 0.2 to 0.4 , and the crystal habit is still that of the lower oxides. It is seen therefore that $\mathrm{UO}_{3} \cdot 2 \mathrm{H}_{2} \mathrm{O}$ can only form on the surface of these oxides and is not contained within the crystalline lattice. Hydrated $\mathrm{UO}_{3}$ is typically yellow in color, is easily spotted, and has been found only in trace quantities on uranium oxides from oxygenated waters. The density of hydrated $\mathrm{UO}_{3}$ is very low and it is easily lifted and removed from surfaces during the cleaning processes.

The entire thrust of this discussion has been to explain why hydrated oxides exist in the floor sludges, but significant quantities of hydrated oxides in the MCO are not expected.

Physically bound water can be found at the oxide surfaces. The bonding energy of physically bond water is typically $10 \mathrm{kcals}$ per mole or less.

Much of the physically bound water is expected to be removed by the CVD process, but it is not certain that it will be quantitatively removed. 
Water will exist at defect sites within the oxide lattice. This water will only migrate out of the oxide readily at higher temperatures than that experienced during CVD. Neither physically bound water nor defect water are expected to be large water sources.

Chemically bound hydroxides are expected to form at the surface of $\mathrm{UO}_{2}$. The normal uranium-oxygen bond angles cannot be maintained at the surface, and structures such as highly strained $\mathrm{U}-\mathrm{O}-\mathrm{U}$, are found. These react readily with water to form:

$$
\mathrm{U}-\mathrm{O}-\mathrm{U}+\mathrm{H}_{2} \mathrm{O}=2 \mathrm{UOH}
$$

Once formed, these hydroxides can migrate into the oxide lattice. The rate of migration is greatly enhanced by an electrical field, as long as the oxide is attached to the metal. When the oxide spalls off, the rate of migration is slowed tremendously.

The bonding energy for these hydroxides is significantly higher than for hydrates involving whole water molecules. As a consequence, the temperatures required to completely remove these hydroxide moieties are typically in the range of 700 to $1000{ }^{\circ} \mathrm{C}$. For this reason, the partial pressure of water from chemically bound hydroxide moieties is so low that they are not of concern for the chemical production of gases during shipping and storage.

It is estimated that the water vapor partial pressure will be approximately 5 torr upon removal from the CVD station. This water vapor pressure is being maintained by any free water still remaining, physically absorbed water, interstitial defect water, and any chemically bound water such as waters of hydration. It is estimated that the entire residual water inventory does not exceed $10 \%$ by volume or $2 \%$ by weight of the entire oxide inventory. For the low sludge case, this would be only 54 grams of water in the MCO. It is obvious that this water inventory will be depleted by the high surface area MCO through chemical reactions with uranium metal until essentially only crystalline defect water and chemically bound hydroxides will remain through shipping and staging.

The calculations for the following tables in this section will use a partial pressure of water vapor of 1 torr. This results from the knowledge that the final water partial pressure at the end of CVD was no more than 5 torr.

After CVD and assuming all free water is removed, the residual water partial pressure will be rapidly depleted to 1 torr or less by continued reaction with the available uranium metal surface.

\subsubsection{Hydrogen Generation From the Reaction of Water with Uranium Metal and Uranium Hydride}

Equation 18 , with a water partial pressure of 1 torr or $0.133 \mathrm{kPa}$, is used to calculate the hydrogen production rate from the reaction of water with uranium metal. The production of hydrogen from uranium hydride does not appear to change significantly for this amount of water 
from the previous case, so it will be carried through unchanged. The results of these calculations are given in Table 5-2 and in Figure 5-2.

\subsubsection{Fission Product Gas Release During Shipping and Staging}

Fission product gases diffuse slowly from the oxide corrosion product. The release rate is too slow to significantly affect the MCO pressure.

\subsubsection{Helium Gas Release During Shipping and Staging}

Helium gas forms from the alpha particles emitted by heavy metals. This helium is not a significant factor in the pressurization of the MCO.

\subsubsection{Water Vapor Pressure Increase During Shipping and Staging}

There is such a small amount of water in the MCO during shipping and staging, that any pressure increase due to water vapor was ignored.

\subsubsection{Pressurization of a Sealed MCO During Shipping and Staging}

To calculate the pressure in a sealed MCO during shipping and staging, the following parameters are assumed:

- Reactive metal surface area $=127,233 \mathrm{~cm}^{2}$ as described for a "worst-case" MCO. (WHC 1996b)

- Sludge mass $=16 \mathrm{~kg}$

- Headspace $=500$ liters

- Temperature $=10^{\circ} \mathrm{C}$

- Radiation energy absorption as described in Tables 2-1 and 2-2

- Time $=1$ hour 
Table 5-2. Chemical Hydrogen Generation in a Sealed MCO During Shipping and Staging.*

\begin{tabular}{|c|c|c|c|c|c|}
\hline \multirow{2}{*}{ Time Hours } & \multicolumn{5}{|c|}{ Temp $\left({ }^{\circ} \mathbf{C}\right)$} \\
\cline { 2 - 6 } & $\mathbf{1 0}$ & $\mathbf{2 0}$ & $\mathbf{5 0}$ & $\mathbf{7 5}$ & 100 \\
\hline 1 & $1.47 \mathrm{E}-07$ & $2.72 \mathrm{E}-07$ & $1.37 \mathrm{E}-06$ & $4.30 \mathrm{E}-06$ & $1.17 \mathrm{E}-05$ \\
\hline 5 & $7.37 \mathrm{E}-07$ & $1.36 \mathrm{E}-06$ & $6.84 \mathrm{E}-06$ & $2.14 \mathrm{E}-05$ & $5.73 \mathrm{E}-05$ \\
\hline 10 & $1.47 \mathrm{E}-06$ & $2.71 \mathrm{E}-06$ & $1.37 \mathrm{E}-05$ & $4.25 \mathrm{E}-05$ & $1.12 \mathrm{E}-04$ \\
\hline 20 & $2.95 \mathrm{E}-06$ & $5.43 \mathrm{E}-06$ & $2.72 \mathrm{E}-05$ & $8.40 \mathrm{E}-05$ & $2.16 \mathrm{E}-04$ \\
\hline 30 & $4.42 \mathrm{E}-06$ & $8.14 \mathrm{E}-06$ & $4.07 \mathrm{E}-05$ & $1.25 \mathrm{E}-04$ & $3.15 \mathrm{E}-04$ \\
\hline 40 & $5.89 \mathrm{E}-06$ & $1.08 \mathrm{E}-05$ & $5.42 \mathrm{E}-05$ & $1.65 \mathrm{E}-04$ & $4.09 \mathrm{E}-04$ \\
\hline 50 & $7.36 \mathrm{E}-06$ & $1.36 \mathrm{E}-05$ & $6.75 \mathrm{E}-05$ & $2.04 \mathrm{E}-04$ & $5.02 \mathrm{E}-04$ \\
\hline 60 & $8.83 \mathrm{E}-06$ & $1.62 \mathrm{E}-05$ & $8.09 \mathrm{E}-05$ & $2.42 \mathrm{D}-04$ & $5.93 \mathrm{E}-04$ \\
\hline 70 & $1.03 \mathrm{E}-05$ & $1.90 \mathrm{E}-05$ & $9.41 \mathrm{E}-05$ & $2.80 \mathrm{E}-04$ & $6.82 \mathrm{E}-04$ \\
\hline 80 & $1.18 \mathrm{E}-05$ & $2.16 \mathrm{E}-05$ & $1.07 \mathrm{E}-04$ & $3.18 \mathrm{E}-04$ & $7.71 \mathrm{E}-04$ \\
\hline 90 & $1.32 \mathrm{E}-05$ & $2.44 \mathrm{E}-05$ & $1.20 \mathrm{E}-04$ & $3.55 \mathrm{E}-04$ & $8.60 \mathrm{E}-04$ \\
\hline 100 & $1.47 \mathrm{E}-05$ & $2.70 \mathrm{E}-05$ & $1.33 \mathrm{E}-04$ & $3.91 \mathrm{E}-04$ & $9.49 \mathrm{E}-04$ \\
\hline 1000 & $1.46 \mathrm{E}-04$ & $2.65 \mathrm{E}-04$ & $1.20 \mathrm{E}-03$ & $3.46 \mathrm{E}-03$ & $8.83 \mathrm{E}-03$ \\
\hline & & & & & \\
\hline & & &
\end{tabular}

* Units are in moles $\mathrm{H}_{2} / \mathrm{cm}^{2}$ 
Figure 5-2. Hydrogen Generation in the MCO During Shipping and Staging.

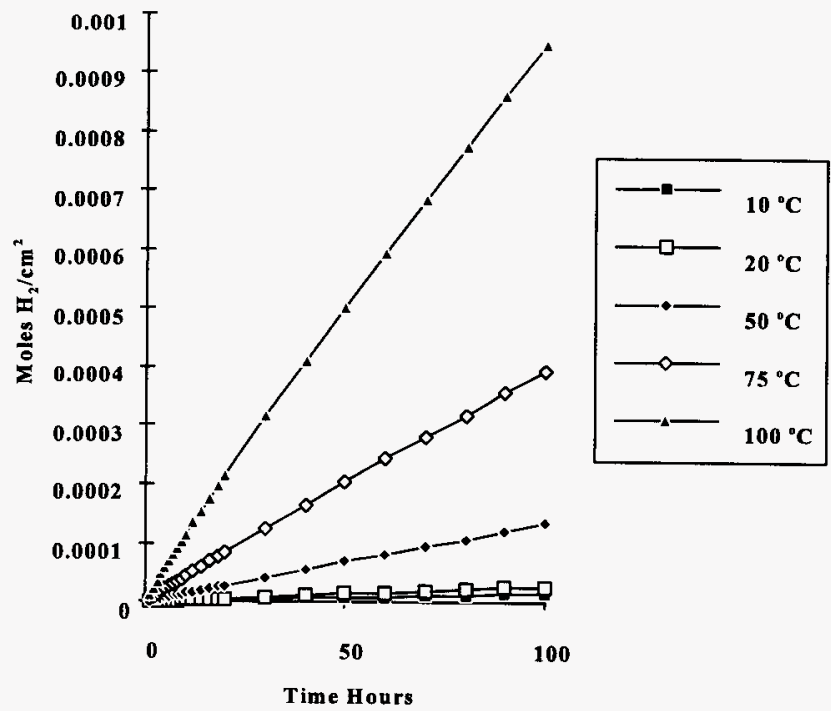


The rate of pressurization of a MCO during shipping and staging can be modeled by summing in the following manner:

Pressure increase in atmospheres $=$

(gmoles radiolysis gases) $+\left(\right.$ reactive metal surface area * $\left(\right.$ gmoles $\mathrm{H}_{2 \text { metal }} / \mathrm{cm}^{2}$

+ gmoles $\left.\left.\mathrm{H}_{2 \mathrm{UH} 3} / \mathrm{cm}^{2}\right)\right) * 0.08205 * 283.16 / 44$

$$
\begin{aligned}
& =((0.0000000096876 * 3600 * 1)+(127233 *(1.307 \mathrm{E}-07)+(0.00029422 * 16)) \\
& * 0.08205 * 283.16 / 44 \\
& =0.00099322 \mathrm{~atm} .
\end{aligned}
$$

The remaining calculations are found in Table 5-3, 5-4, 5-5 and Figure 5-3, 5-4, 5-5.

\subsubsection{Reduction of Inventory of Reactants}

For the calculations performed in this section, it has been assumed that the water partial pressure remains constant at 1 torr and that the inventory of uranium hydride remains constant in the oxide corrosion product. In fact, either can be depleted. Water has been steadily depleted by draining, CVD, and chemical reaction with the exposed uranium metal. Uranium metal is a more powerful water "getter" than any other material and will eventually react all of the water in the system.

The reaction rates of water with uranium metal at water pressures below 1 torr cannot be accurately modeled with existing late data, and we have chosen to remain at that level for the sake of conservatism. Because of the depletion of water, the higher pressures predicted in preceding graphs in this section are not actually achievable.

It was estimated at the beginning of this section that no more than 3 wt $\%$ of water would survive in the sludge after CVD. For $16 \mathrm{~kg}$ of sludge, this limits the pressure increase in a given MCO to 1.65 atmospheres. Larger amounts of sludge could yield proportionately more pressure.

Since water reacts with uranium metal to form uranium hydride, and with uranium hydride to form uranium oxide, uranium hydride exists in secular equilibrium. Once the supply of water is exhausted, it becomes quite possible to oxidize the remaining hydride. The oxidation rate with oxygen gas is extremely fast. Data from S. Robinson shows complete oxidation (at $0-100{ }^{\circ} \mathrm{C}$ ) of samples of pure uranium hydride in 200 torr oxygen within 6 minutes (Robinson 1996). 
Table 5-3. Pressure Increase for a MCO During Shipping and Staging.

\begin{tabular}{|c|c|c|c|c|c|}
\hline \multirow[b]{2}{*}{ Time Hours } & \multicolumn{5}{|c|}{$\operatorname{Temp}\left({ }^{\circ} \mathrm{C}\right)$} \\
\hline & 10 & 20 & 50 & 75 & 100 \\
\hline 1 & $8.10 \mathrm{E}-04$ & 0.0024 & 0.0157 & 0.0484 & 0.1241 \\
\hline 5 & $4.05 \mathrm{E}-03$ & 0.0083 & 0.0445 & 0.1364 & 0.3543 \\
\hline 10 & $8.10 \mathrm{E}-03$ & 0.0157 & 0.0805 & 0.2459 & 0.6373 \\
\hline 20 & 0.0162 & 0.0305 & 0.1525 & 0.4630 & 1.1903 \\
\hline 30 & 0.0243 & 0.0453 & 0.2242 & 0.6775 & 1.7281 \\
\hline 40 & 0.0324 & 0.0600 & 0.2957 & 0.8903 & 2.2594 \\
\hline 50 & 0.0405 & 0.0748 & 0.3671 & 1.1017 & 1.3117 \\
\hline 60 & 0.0486 & 0.0896 & 0.4383 & 1.3117 & 3.3104 \\
\hline 70 & 0.0566 & 0.1043 & 0.5094 & 1.5206 & 3.8324 \\
\hline 80 & 0.0648 & 0.1191 & 0.5804 & 1.7286 & 4.3531 \\
\hline 90 & 0.0728 & 0.1338 & 0.6513 & 1.9357 & 4.8730 \\
\hline 100 & 0.0810 & 0.1486 & 0.7220 & 2.1419 & 5.3923 \\
\hline 1000 & 0.8033 & 1.4533 & 6.7617 & 20.178 & 52.022 \\
\hline
\end{tabular}

* Units are in atmospheres pressure. 
Figure 5-3. Pressure Increase for a "Worst-Case" MCO

Containing $2.7 \mathrm{~kg}$ of Sludge During Shipping and Staging.

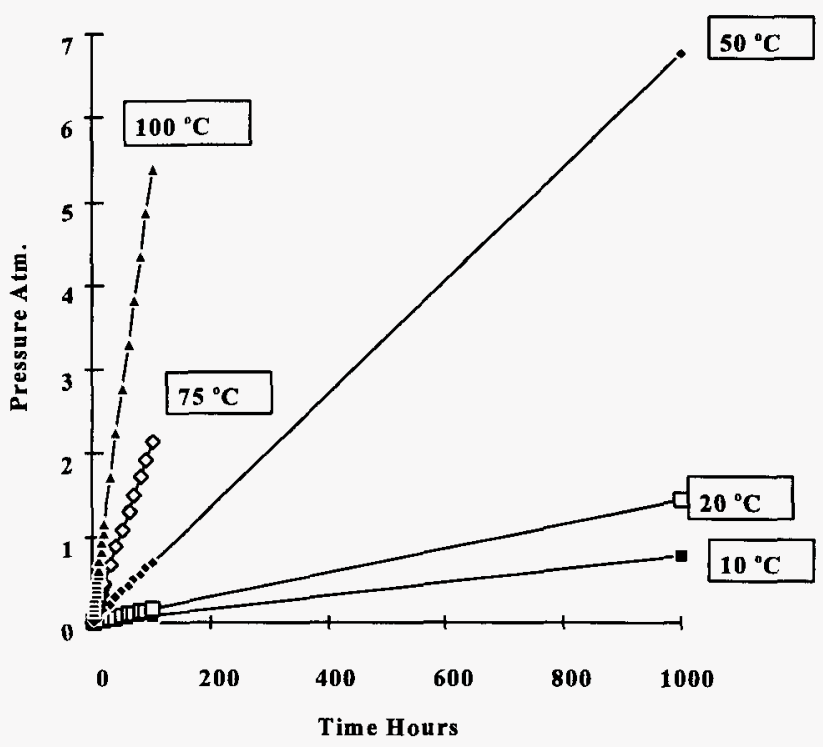

Figure 5-3 shows for a sealed "worst case" MCO containing $2.7 \mathrm{~kg}$ of sludge, the nominal 10 atmosphere pressure limit is reached in 12843 hours at $10^{\circ} \mathrm{C}$, in 7090 hours at $20^{\circ} \mathrm{C}$, in 1485 hours at $50^{\circ} \mathrm{C}$, in 492 hours at $75^{\circ} \mathrm{C}$, and in 189 hours at $100^{\circ} \mathrm{C}$. 
Table 5-4. Pressure Increase for a "Worst-Case" MCO Containing $16 \mathrm{~kg}$ Sludge During Shipping and Staging.

\begin{tabular}{|c|c|c|c|c|c|}
\hline \multirow{2}{*}{ Time Hours } & \multicolumn{5}{|c|}{ Temp ${ }^{\circ}{ }^{\circ}$ C) } \\
\cline { 2 - 6 } & $\mathbf{1 0}$ & $\mathbf{2 0}$ & $\mathbf{5 0}$ & $\mathbf{7 5}$ & $\mathbf{1 0 0}$ \\
\hline 1 & $9.93 \mathrm{E}-04$ & 0.0028 & 0.0183 & 0.0584 & 0.1553 \\
\hline 5 & $4.97 \mathrm{E}-03$ & 0.0103 & 0.0575 & 0.1849 & 0.4985 \\
\hline 10 & $9.93 \mathrm{E}-03$ & 0.0196 & 0.1063 & 0.3399 & 0.8994 \\
\hline 20 & 0.0199 & 0.0382 & 0.2031 & 0.6395 & 1.6240 \\
\hline 30 & 0.0298 & 0.0568 & 0.2986 & 0.9232 & 2.2588 \\
\hline 40 & 0.0397 & 0.0754 & 0.3932 & 1.1970 & 2.8550 \\
\hline 50 & 0.0496 & 0.0939 & 0.4869 & 1.4623 & 3.4252 \\
\hline 60 & 0.0595 & 0.1124 & 0.5798 & 1.7200 & 3.9780 \\
\hline 70 & 0.0693 & 0.1309 & 0.6718 & 1.9708 & 4.5194 \\
\hline 80 & 0.0793 & 0.1494 & 0.7631 & 2.2159 & 5.0530 \\
\hline 90 & 0.0892 & 0.1679 & 0.8536 & 2.4556 & 5.5814 \\
\hline 100 & 0.0991 & 0.1863 & 0.9436 & 2.6907 & 6.1063 \\
\hline 1000 & 0.9533 & 1.7117 & 7.0912 & 20.718 & 52.719 \\
\hline
\end{tabular}


Figure 5-4. Pressure Increase for a "Worst-Case" MCO Containing $16 \mathrm{~kg}$ of Sludge During Shipping and Staging.

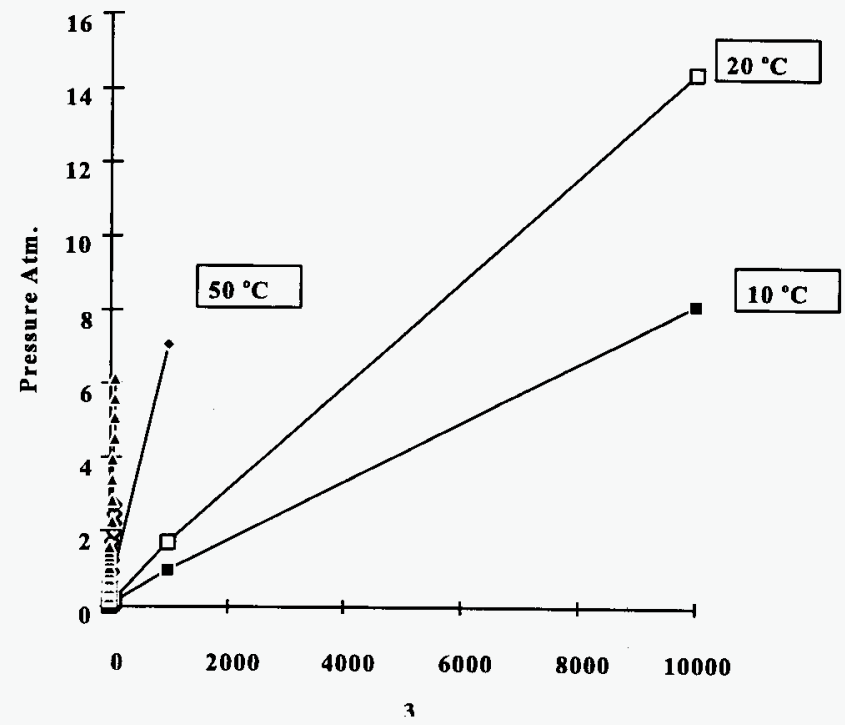

Figure 5-4 shows that for a sealed MCO containing $16 \mathrm{~kg}$ of sludge, the nominal 10 atmosphere limit is reached in 12373 hours at $10^{\circ} \mathrm{C}, 6839$ hours at $20^{\circ} \mathrm{C}, 1436$ hours at $50^{\circ} \mathrm{C}$, 465171 hours at $75^{\circ} \mathrm{C}$, and within 175 hours at $100^{\circ} \mathrm{C}$. 
Table 5-5. Pressure Increase for a "Worst-Case" MCO Containing $277 \mathrm{~kg}$ Sludge During Shipping and Staging.

\begin{tabular}{|c|c|c|c|c|c|}
\hline \multirow{2}{*}{ Time Hours } & \multicolumn{5}{|c|}{ Temp $\left.{ }^{\circ} \mathbf{C}\right)$} \\
\cline { 2 - 6 } & $\mathbf{1 0}$ & $\mathbf{2 0}$ & $\mathbf{5 0}$ & $\mathbf{7 5}$ & $\mathbf{1 0 0}$ \\
\hline 1 & 0.0046 & 0.0102 & 0.0692 & 0.2536 & 0.7680 \\
\hline 5 & 0.0228 & 00474 & 0.3105 & 1.1371 & 3.3295 \\
\hline 10 & 0.0457 & 0.0938 & 0.6083 & 2.1867 & 6.0456 \\
\hline 20 & 0.0914 & 0.1863 & 1.1903 & 4.1065 & 10.143 \\
\hline 30 & 0.1369 & 0.2783 & 1.7497 & 5.7500 & 12.685 \\
\hline 40 & 0.1824 & 0.3698 & 2.2934 & 7.2244 & 14.557 \\
\hline 50 & 0.2277 & 0.4610 & 2.8220 & 8.5495 & 15.980 \\
\hline 60 & 0.2730 & 0.5519 & 3.3360 & 9.7426 & 17.104 \\
\hline 70 & 0.3182 & 0.6424 & 3.8358 & 10.820 & 18.027 \\
\hline 80 & 0.3633 & 0.7326 & 4.3219 & 11.794 & 18.816 \\
\hline 90 & 0.4083 & 0.8223 & 4.7946 & 12.677 & 19.515 \\
\hline 100 & 0.4533 & 0.9118 & 5.2545 & 13.484 & 20.154 \\
\hline 1000 & 3.8869 & 6.6305 & 13.233 & 31.5253 & 66.784 \\
\hline
\end{tabular}

* Units are in atmospheres pressure. 
Figure 5-5. Pressure for a "Worst-Case" MCO Containing $277 \mathrm{~kg}$ of Sludge During Shipping and Staging.

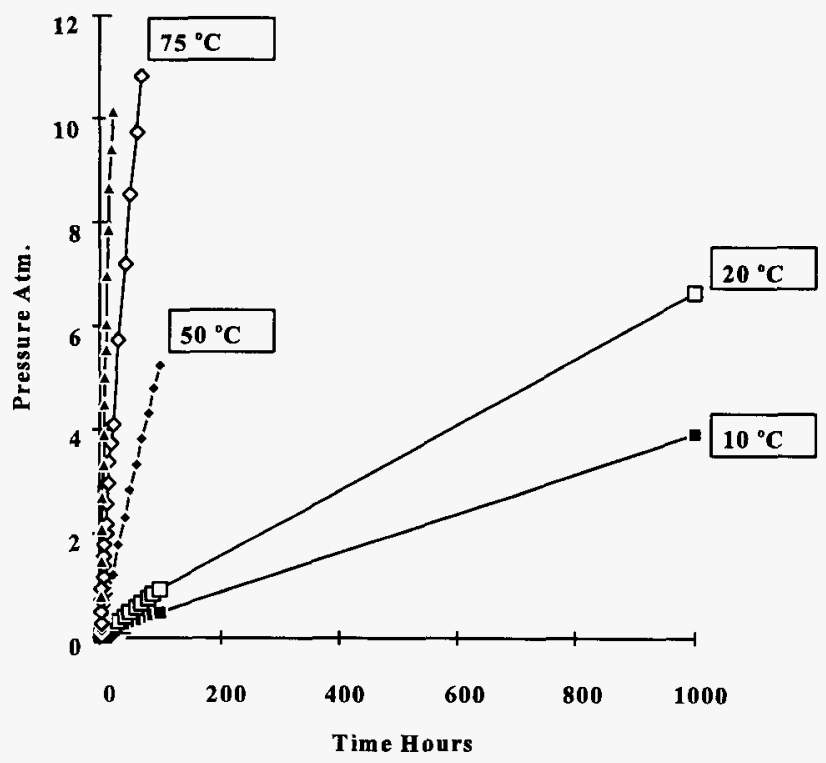

Figure 5-5 shows that for a sealed MCO containing $277 \mathrm{~kg}$ of sludge, the nominal 10 atmosphere limit is reached in 3392 hours at $10^{\circ} \mathrm{C}, 1671$ hours at $20^{\circ} \mathrm{C}, 256$ hours at $50{ }^{\circ} \mathrm{C}$, 62.2 hours at $75^{\circ} \mathrm{C}$, and within 19.6 hours at $100^{\circ} \mathrm{C}$. 
WHC-SD-SNF-TI-028

Revision 0

This page intentionally left blank. 


\subsection{GAS GENERATION DURING HOT VACUUM DRYING (HVD) AND CONDITIONING}

Gas generation during HVD and conditioning is not expected to be significant. Although these process steps contain the maximum temperatures, all of the free and physically bound water has been eliminated prior to this step, and a good share of the chemically bound water will have also been eliminated due to radiolysis and chemical reaction during staging.

During hot vacuum drying, most of the remaining chemically bound water will be released as the $\mathrm{MCO}$ is heated to $300^{\circ} \mathrm{C}$. This is not expected to pressurize the MCO be cause the system is being actively vacuum pumped. By the time the MCO reaches Hot Conditioning, the water inventory is so low that no significant pressurization will occur.

Pressurization from radiolysis gases is not expected to be significant during HVD or Hot Conditioning because of the short time interval during these process steps. Calculations substantiating these statements will be released in the near future. 
WHC-SD-SNF-TI-028

Revision 0

This page is intentionally left blank. 


\subsection{GAS GENERATION DURING LONG-TERM STORAGE}

\subsection{RADIOLYTIC GAS GENERATION DURING LONG-TERM STORAGE}

Radiolytic gases are generated during long-term storage. After hot vacuum drying and conditioning, the only water in the MCO should be chemically adsorbed water. This water can either be dissociated into hydroxide ions on the oxide surfaces, or can be molecular water associated with hydrate forming metal ions. Although this water is chemically bound and is very stable, radiolysis is a very high energy event and releases both hydrogen and oxygen gases.

The rate of radiolysis depends upon the radiation fields, the specific surface phenomena occurring, and the quantity of water absorbing energy. The rate equations are:

where:

$$
\begin{aligned}
& \mathrm{dn} / \mathrm{dt}=\mathrm{k}_{\mathrm{t}}{ }^{*} \mathrm{G}_{1}{ }^{*} \mathrm{~N}+\mathrm{k}_{2}{ }^{*} \mathrm{G}_{2} * \mathrm{~N}+\mathrm{k}_{3} * \mathrm{G}_{3} * \mathrm{~N} \\
& =\left(\mathrm{k}_{1}{ }^{*} \mathrm{G}_{1}+\mathrm{k}_{2} * \mathrm{G}_{2}+\mathrm{k}_{3}{ }^{*} \mathrm{G}_{3}\right) * \mathrm{~N}
\end{aligned}
$$

$k_{1}=$ the alpha energy absorbed per gmole of water

$k_{2}=$ the beta energy absorbed per gmole of water

$\mathrm{k}_{\hat{\mathrm{j}}}=$ the gamma energy absorbed per gmole of water

$\mathrm{G}_{1}=\# \mathrm{H}_{2} / 100$ ev alpha

$\mathrm{G}_{2}=\# \mathrm{H}_{2} / 100$ ev beta

$\mathrm{G}_{3}=\# \mathrm{H}_{2} / 100$ ev gamma

all of the preceding constants can be combined mathematically into one large constant $\mathrm{K}$, so with the definition:

$$
\mathrm{N}=\text { the number of gmoles of water acting as radiolysis targets }
$$

This gives the easily recognizable first order equation whose solution is:

$$
\mathrm{N} / \mathrm{No}_{\mathrm{o}}=\operatorname{Exp}[-\mathrm{Kt}]
$$

This equation can be used to calculate the amount of water remaining at any time t.

\section{Calculation of $\mathrm{K}$}

From Table 2-1:

$$
\begin{gathered}
\mathrm{k}_{1}{ }^{*} \mathrm{G}_{1}=(3600 \mathrm{sec} / \mathrm{hour}) *(1.62 \mathrm{E}-05 \mathrm{~J} / \mathrm{g}-\mathrm{sec}) *(6.2112 \mathrm{E}+18 \mathrm{ev} / \mathrm{J}) * \\
(18 \mathrm{~g} / \mathrm{m}) *(3 \mathrm{molecules} / 100 \mathrm{ev}) *(1 \mathrm{~mole} / 6.023 \mathrm{E}+23 \mathrm{molecules})
\end{gathered}
$$




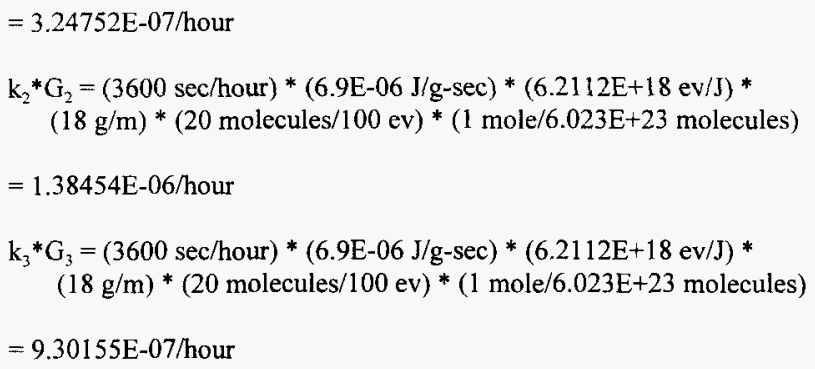$$
=1.38454 \mathrm{E}-06 / \text { hour }
$$$$
\mathrm{k}_{3}{ }^{*} \mathrm{G}_{3}=(3600 \mathrm{sec} / \mathrm{hour}) *(6.9 \mathrm{E}-06 \mathrm{~J} / \mathrm{g}-\mathrm{sec}) *(6.2112 \mathrm{E}+18 \mathrm{ev} / \mathrm{J}) *
$$$$
(18 \mathrm{~g} / \mathrm{m}) *(20 \mathrm{molecules} / 100 \mathrm{ev}) *(1 \mathrm{~mole} / 6.023 \mathrm{E}+23 \text { molecules })
$$$$
=9.30155 \mathrm{E}-07 / \text { hour }
$$

so

$$
\mathrm{K}=2.63143 \mathrm{E}-06 / \text { hour }
$$

Now the fraction of water remaining after any time $t$ can be defined

$$
\mathrm{N} / \mathrm{No}_{0}=\operatorname{Exp}\left[-2.63143 \mathrm{E}-06^{*} \mathrm{t}\right]
$$

This equation is shown graphically in Figure 6-1. 
Figure 7-1. Water Remaining in MCO During Long-term Storage.

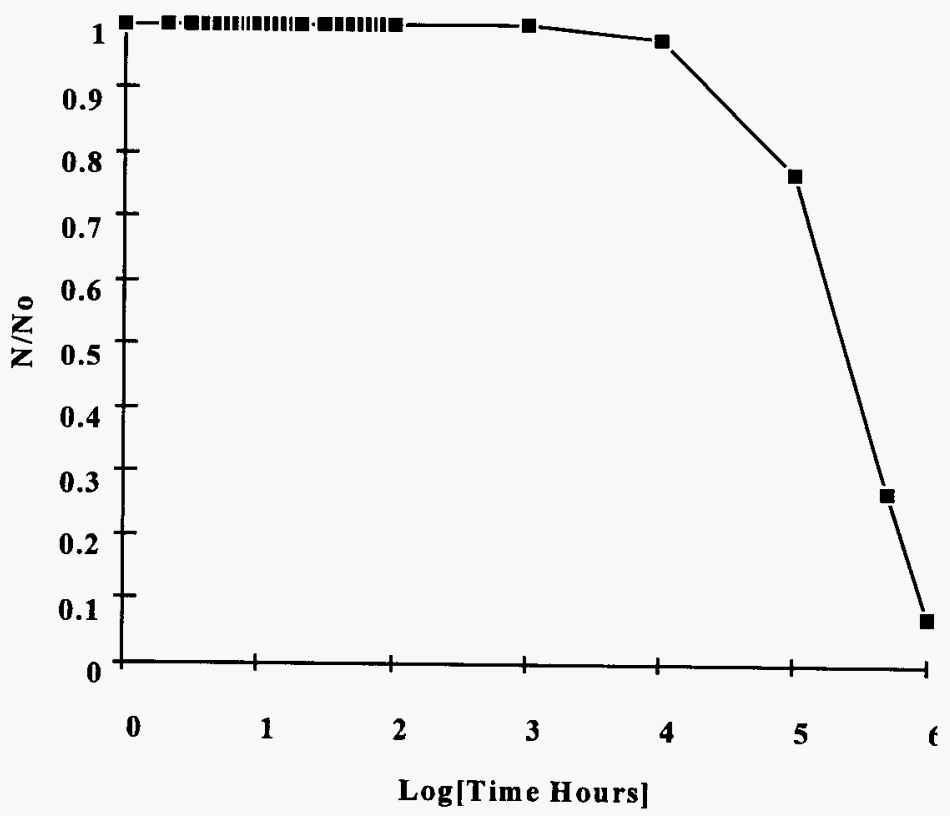

Now specific cases can be calculated and are included in Table 6-1 and Figures 62 and $6-3$. 
Table 7-1. Water Radiolyzed During Long-term Storage.*

\begin{tabular}{|c|c|c|c|c|}
\hline $\begin{array}{l}\text { Wt\% } \\
\text { Water }\end{array}$ & $\begin{array}{c}\text { Log } \\
\text { Hours }\end{array}$ & $2.7 \mathrm{~kg}$ & $16 \mathrm{~kg}$ & $277 \mathrm{~kg}$ \\
\hline \multirow[t]{7}{*}{0.5} & 0 & $1.9736 \mathrm{E}-06$ & $1.1695 \mathrm{E}-05$ & $2.0247 \mathrm{E}-04$ \\
\hline & 1 & $1.9735 \mathrm{E}-05$ & $1.1695 \mathrm{E}-04$ & $2.0247 \mathrm{E}-03$ \\
\hline & 2 & $1.9733 \mathrm{E}-04$ & $1.1694 \mathrm{E}-04$ & $2.0221 \mathrm{E}-02$ \\
\hline & 3 & $1.9710 \mathrm{E}-03$ & $1.1680 \mathrm{E}-02$ & $2.0221 \mathrm{E}-01$ \\
\hline & 4 & $1.9478 \mathrm{E}-02$ & $1.1680 \mathrm{E}-01$ & $1.9983 \mathrm{E}-00$ \\
\hline & 5 & $1.7353 \mathrm{E}-01$ & $1.0283 \mathrm{E}-00$ & $1.7802 \mathrm{E}+01$ \\
\hline & 6 & $6.9602 E-01$ & $4.1245 \mathrm{E}-00$ & $7.1406 \mathrm{E}+01$ \\
\hline \multirow[t]{7}{*}{$1.5^{* *}$} & 0 & $5.9207 \mathrm{E}-06$ & $3.5086 \mathrm{E}-05$ & $6.0742 \mathrm{E}-04$ \\
\hline & 1 & $5.9206 \mathrm{E}-05$ & $3.5085 \mathrm{E}-04$ & $6.0741 \mathrm{E}-03$ \\
\hline & 2 & $5.9199 \mathrm{E}-04$ & $3.5081 \mathrm{E}-03$ & $6.0734 \mathrm{E}-02$ \\
\hline & 3 & $5.9129 \mathrm{E}-03$ & $3.5040 \mathrm{E}-02$ & $6.0662 \mathrm{E}-01$ \\
\hline & 4 & $5.8435 \mathrm{E}-02$ & $3.4628 \mathrm{E}-01$ & $5.9950 \mathrm{E}-00$ \\
\hline & 5 & $5.2058 \mathrm{E}-01$ & $3.0849 \mathrm{E}-00$ & $5.3407 \mathrm{E}+01$ \\
\hline & 6 & $2.0881 E-00$ & $1.2374 \mathrm{E}+01$ & $2.1422 \mathrm{E}+02$ \\
\hline
\end{tabular}

* Units are in gmoles water radiolyzed, which correspond numerically to gmoles of hydrogen produced. The number of gmoles of oxygen produced are half the number of gmoles of hydrogen.

** Even though only 0.5 weight $\%$ is expected after hot vacuum conditioning, a 1.5 weight $\%$ water case was added to extend the range of water considered during long-term storage. 
Figure 7-2. Water Radiolyzed During Long-term Storage From Sludge Containing $0.5 \mathrm{wt} \%$ Water.

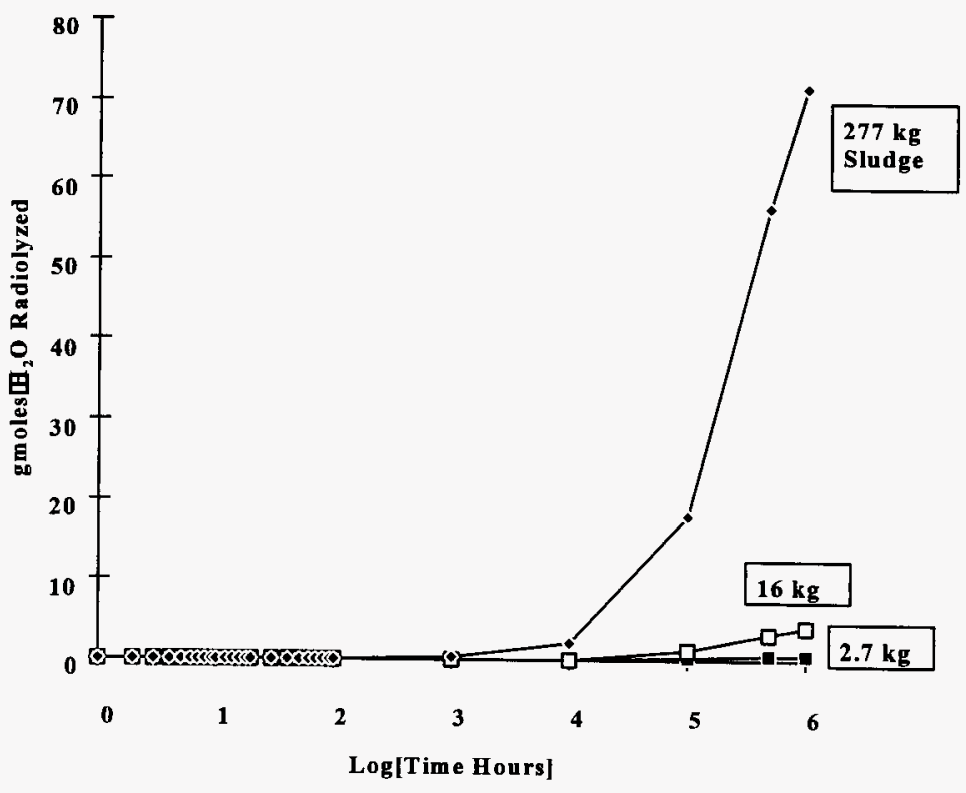

* Initial wt \% water was 0.5 . 
Figure 7-3. Water Radiolyzed During Long-term Storage

From Sludge Containing $1.5 \mathrm{wt} \%$ Water.

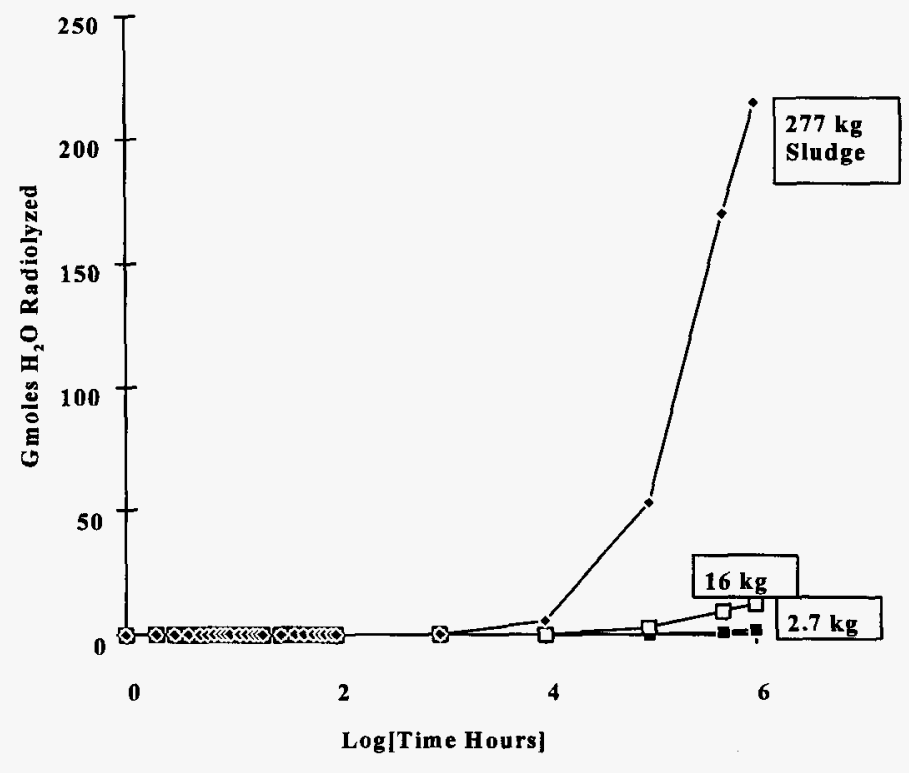

* $1.5 \mathrm{wt} \%$ water.

Pressures from this radiolysis process will depend upon the equilibrium MCO temperature and can be calculated from the number of moles radiolyzed.

\subsection{CHEMICAL GAS GENERATION}

It is certainly. possible for gases to be generated chemically during long-term storage if any water molecules strike uranium metal. It is expected that the rate will be very slow as the partial pressure of water in the $\mathrm{MCO}$ is expected to be extremely low. Since we cannot model either the water pressure or the reaction rate accurately, it is conservatively assumed that if exposed uranium metal is available and chemical reactions are possible, all of the available hydrogen on water will be transformed to hydrogen gas. Some fraction of that hydrogen (possibly all) will be converted to uranium hydride by further chemical reactions over the long storage time. 


\subsection{REFERENCES}

Barrow, G.M., 1961, Physical Chemistry, pp 483, McGraw-Hill Book Company, Incorporated.

Baker, M. McD., Less, L.N., and Orman, S., 1966, Uranium + Water Reaction, Trans. Farad. Soc. 62 2513-2530.

Owczarski, P., 1996, Personal Communication.

Pearce, R.J., 1989, A Review of the Rates of Reaction of Unirradiated Uranium in Gaseous Atmospheres, Report RD/B/6231/R89, Central Electricity Generating Board, Berkeley Nuclear Laboratories, Berkley, England.

Rasmussen, O.R.H., 1969, Ceramic Properties of Plutonium Dioxide, ARH 1153.

Ritchie, A G., 1981, Journal of Nuclear Materials, 102 (1981) 170.

Robinson, S., 1996, Personal Communication, Lawrence Livermore National Laboratory, Livermore, California.

WHC, 1996a, KE Basin Underwater Visual Fuel Survey, WHC-SD-SNF-TI-012, Westinghouse Hanford Company, Richland, Washington

WHC, 1996b, Surface Area Estimates for N-Fuel in K-East Basin, WHC-SD-SNF-TI031, Westinghouse Hanford Company, Richland, Washington.

WHC, 1996c, Photon Heat Deposition Calculations for Hydrogen Generation Within $M C O$, WHC-SD-SNF-TI-027 Preliminary Informal Report, Westinghouse Hanford Company, Richland, Washington.

WHC, 1996d, Detonation Phenomena of Hydrogen/Oxygen in Spent Fuel Containers, WHC-SD-SNF-TI-021, Westinghouse Hanford Company, Richland, Washington. 
WHC-SD-SNF-TI-028

Revision 0

This page intentionally left blank. 


\section{DISTRIBUTION SHEET}

\begin{tabular}{|c|c|c|c|c|c|}
\hline \multirow{2}{*}{$\begin{array}{l}\text { To } \\
\text { Distribution }\end{array}$} & \multirow{2}{*}{\multicolumn{3}{|c|}{$\begin{array}{l}\text { From } \\
\text { Plutonium Process Support } \\
\text { Laboratory/Thurman Cooper }\end{array}$}} & \multicolumn{2}{|l|}{ Page 1 of 1} \\
\hline & & & & \multicolumn{2}{|l|}{ Date $07 / 22 / 96$} \\
\hline \multirow{2}{*}{\multicolumn{4}{|c|}{$\begin{array}{l}\text { Project Title/Work Order } \\
\text { Spent Nuclear Fuel Project (SNFP) Gas Generation From N-Fuel in Multi- } \\
\text { Canister Overpacks. WHC-SD-SNF-TI-028. Revision } 0\end{array}$}} & \multicolumn{2}{|c|}{ EDT No. 616631} \\
\hline & & & & \multicolumn{2}{|l|}{ ECN No. N/A } \\
\hline Name & MSIN & $\begin{array}{c}\text { Text } \\
\text { With } \\
\text { All } \\
\text { Attach. }\end{array}$ & Text Only & $\begin{array}{l}\text { Attach./ } \\
\text { Appendix } \\
\text { Only }\end{array}$ & $\begin{array}{c}\text { EDT/ECN } \\
\text { Only }\end{array}$ \\
\hline J Abrefah & P7-34 & $x$ & & & \\
\hline GS Barney & T5- 12 & $x$ & & & \\
\hline GD Bazinet & B4 -55 & $x$ & & & \\
\hline LD Blackburn & $R 1-56$ & $x$ & & & \\
\hline TD Cooper & $\mathrm{T} 5-12$ & $x$ & & & \\
\hline RG Cowan & R3-86 & $x$ & & & \\
\hline ER Cramer & $\mathrm{H} 0-34$ & $x$ & & & \\
\hline DR Duncan & R3-86 & $\hat{x}$ & & & \\
\hline FO Fisher & $\mathrm{T} 5-12$ & $x$ & & & \\
\hline JR Frederickson & $R 3-86$ & $x$ & & & \\
\hline FJ Heard & $\mathrm{HO}-34$ & $x$ & & & \\
\hline Jj Irwin & HO- -34 & $x$ & & & \\
\hline A Johnson & $K 8-34$ & $x$ & & & \\
\hline AT kee & $R 3-86$ & $x$ & & & \\
\hline CR Miska & $R 3-86$ & $x$ & & & \\
\hline SD Nunn & $S 5-11$ & $x$ & & & \\
\hline DM Ogden & $\mathrm{HO}-34$ & $x$ & & & \\
\hline PA Scott & $R 3-87$ & $x$ & & & \\
\hline PK Shen & $\mathrm{HO}-40$ & $x$ & & & \\
\hline DA Smith & $\mathrm{R} 3-11$ & $x$ & & & \\
\hline TA Tharnton & P7-18 & $x$ & & & \\
\hline JC wiborg & R3 -86 & $x$ & & & \\
\hline AM Zaman & B1- 10 & $x$ & & & \\
\hline Central Files (orng +1 ) & $A 3-88$ & $x$ & & & \\
\hline SNF Project files & $\mathrm{R} 3-11$ & $x$ & & & \\
\hline J.S.Lan & .40 .35 & $x$ & & & \\
\hline J. Greenborg & Ho- 35 & $x$ & & & \\
\hline
\end{tabular}

